\title{
Studies Directed toward the Synthesis of Aspidophytine: Construction of Its Perhydroquinoline Core
}

\author{
Yunus E. Türkmen, ${ }^{\dagger}$ Michel Gravel, ${ }^{\ddagger}$ and Viresh H. Rawal ${ }^{*}, \S$ \\ Department of Chemistry, University of Chicago, 5735 South Ellis Avenue Chicago, Illinois 60637, United States
}

Supporting Information

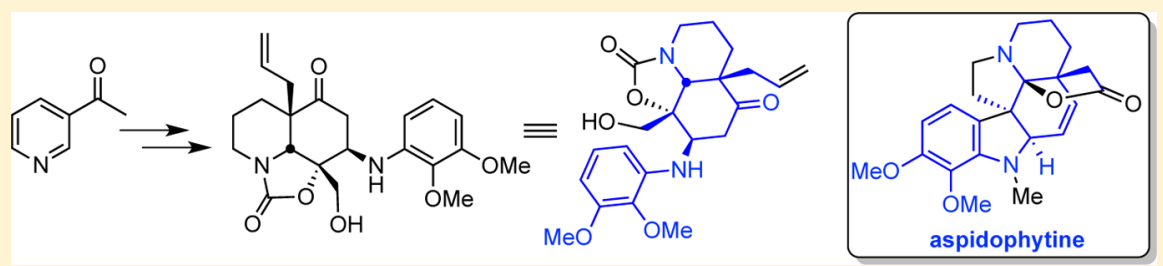

ABSTRACT: We have developed an efficient route for the synthesis of the perhydroquinoline core of the indole alkaloid aspidophytine (2), starting from commercially available and inexpensive 3-acetylpyridine. This densely functionalized perhydroquinoline core displays four contiguous stereocenters including an all-carbon quaternary center. The synthetic sequence features a highly effective Diels-Alder reaction using a carbamate-substituted siloxy diene accompanied by a spontaneous intramolecular substitution of the newly formed $3^{\circ}$-alkyl bromide with a carbamate group. The installation of the electron-rich aniline moiety was accomplished via a TBSOTf-mediated intramolecular aza-Michael reaction, and the relative stereochemistry of the aza-Michael product (30) was confirmed by X-ray crystallographic analysis. Among the useful transformations that were developed through this study is a highly enantioselective Diels-Alder reaction of a versatile cyclic carbamate siloxy diene.

\section{INTRODUCTION}

Haplophytine (1) is a heterodimeric indole alkaloid first isolated by Snyder and co-workers in 1952 (Figure 1 ). ${ }^{1}$ It is the

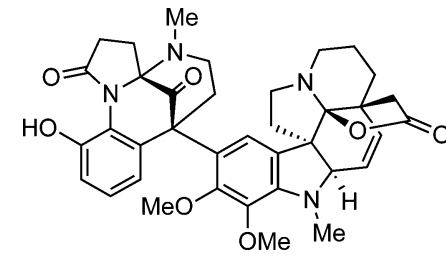

haplophytine (1)

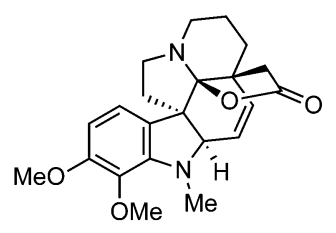

aspidophytine (2)
Figure 1. Indole alkaloids haplophytine (1) and aspidophytine (2).

major constituent of an insecticidal/anticockroach powder prepared from the dried leaves of the Mexican plant Haplophyton cimicidum (family Apocynaceae). ${ }^{2}$ The structure elucidation of haplophytine (1) was accomplished in 1973 after the extensive efforts of Cava, Yates, and Zacharias, which included spectroscopic, crystallographic, and chemical degradation studies. ${ }^{3}$ More recently, Alam and co-workers reported the isolation of 15 alkaloids from Haplophyton crooksii (Apocynaceae), and haplophytine, one of the alkaloids isolated in this study, was found to exhibit moderate in vitro inhibition of acetylcholinesterase activity. ${ }^{4}$

Given its highly complex and synthetically challenging structure, it is not surprising that haplophytine has attracted significant attention from leading laboratories in the synthetic community. ${ }^{5,6}$ Many of the initial efforts were directed toward the total synthesis of its right-hand domain, aspidophytine (2), which is thought to be the key biosynthetic and synthetic precursor to haplophytine (1), as well as the acidic degradation product of the natural product. ${ }^{3 c}$ In 1999, Corey and coworkers reported the first total synthesis of aspidophytine, which proceeded through an ingenious tricyclization of a tryptamine derivative. Several other research groups followed up with their own creative solutions to the alkaloid target. ${ }^{7}$ The total synthesis of haplophytine (1) has been accomplished by the groups of Fukuyama/Tokuyama and Nicolaou/Chen. ${ }^{6}$

In 1997, our group contributed amino siloxy dienes to chemists' repertoire of dienes for organic synthesis. ${ }^{8,9}$ Not only are these dienes highly reactive, allowing reactions to take place at considerably lower temperature than well established dienes, but also they give cycloadducts with near complete endoselectivity with several different types of dienophiles. Of special significance is that these dienes give rise to highly functionalized cycloadducts in which a nitrogen atom has been introduced in a stereocontrolled manner. These attributes make amino siloxy dienes powerful synthons for natural products synthesis, and this capability has been demonstrated by us ${ }^{10}$ and others ${ }^{11}$ through successful total syntheses. For example, in the synthesis of tabersonine (3), ${ }^{10 \mathrm{~b}}$ and subsequently its asymmetric synthesis and that of vindoline, ${ }^{10 c, d}$ we constructed the $C$-ring of the alkaloid by the Diels-Alder

Special Issue: Heterocycles

Received: June 30, 2016

Published: August 15, 2016 
reaction of diene $\mathbf{4}$ and dienophile 5 , leading to the formation of bonds $a$ and $b$ (Scheme 1). For the synthesis of

Scheme 1. Alternate Bond Disconnections in the Retrosyntheses of Tabersonine (3) and Aspidophytine (2)

Earlier work: Rawal, 1998, Ref. 10b

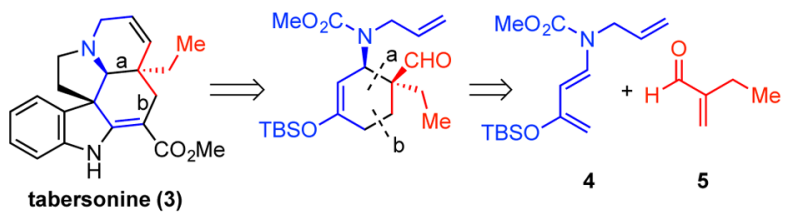

This work

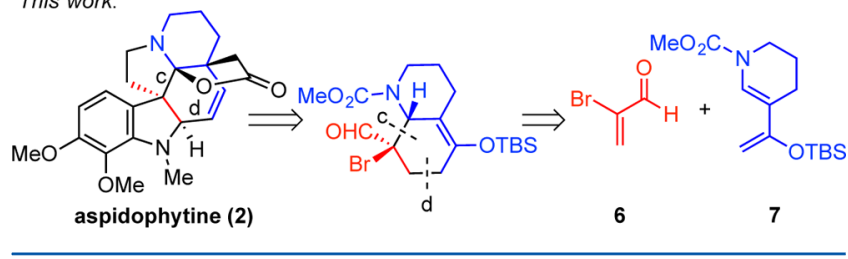

aspidophytine, we opted to undertake a different strategy to show the versatility of amino and carbamate siloxy dienes. In this alternate approach, dienophile 6 and diene 7 were selected as the Diels-Alder reaction partners, such that their cycloaddition would construct the alkaloid core via the formation of bonds $c$ and $d$ instead of $a$ and $b$ (Scheme 1).

A fuller strategy to aspidophytine (2) based on the alternate cycloaddition reaction was devised, as detailed in a retrosynthetic sense in Scheme 2. According to this analysis, the

Scheme 2. Retrosynthesis of Aspidophytine (2)

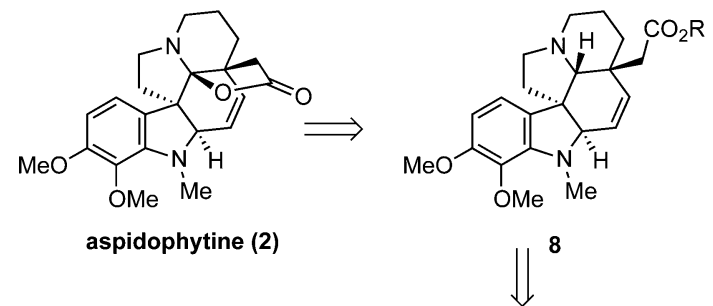
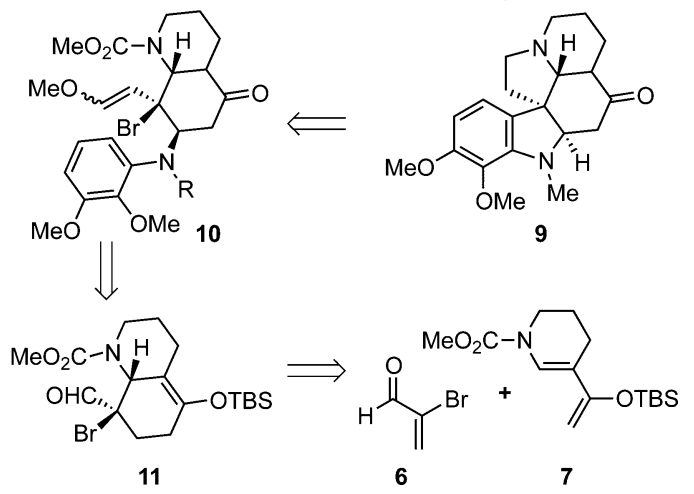

target would be prepared from ester $\mathbf{8}$ by the oxidative lactone formation methodology that was nicely utilized by Corey and co-workers in their total synthesis of aspidophytine. ${ }^{7 a}$ Ester 8 was then expected to be synthesized from ketone 9 by the $\alpha$ alkylation followed by its conversion to the alkene. A challenging step in the planned sequence was expected to be construction of the all-carbon quaternary center of the indoline unit of $\mathbf{9}$ from intermediate 10. Treatment of $\mathbf{1 0}$ with a Lewis acid or a silver(I) salt was expected to promote departure of the bromide, resulting in the formation of a carbocation that would be stabilized by the electron-donating methoxyvinyl group. An intramolecular Friedel-Crafts-type cyclization reaction between the electron-rich aniline ring and the newly formed carbocation would form the needed $\mathrm{C}-\mathrm{C}$ bond, resulting in the formation of the indoline unit. Intermediate $\mathbf{1 0}$ was expected to be synthesized by an intermolecular aza-Michael reaction between the requisite aniline derivative and the enone, which would in turn be obtained from silyl enol ether 11. Finally, in another pivotal step, the fused bicyclic intermediate 11 would be generated by a Diels-Alder reaction between carbamate siloxy diene 7 and 2-bromoacrolein (6).

\section{RESULTS AND DISCUSSION}

The required carbamate siloxy diene 7 was prepared in three steps starting from commercially available and inexpensive 3acetylpyridine (Scheme 3). ${ }^{12}$ Hydrogenation of 3-acetylpyr-

Scheme 3. Diels-Alder Reaction of Diene 7 with 2Bromoacrolein
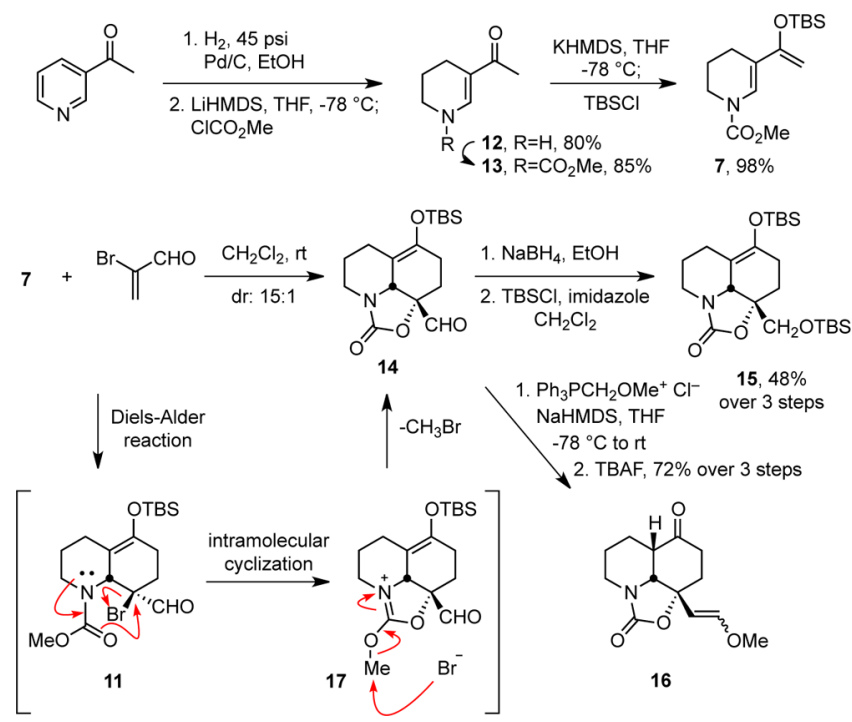

16

idine under an atmosphere of $\mathrm{H}_{2}$ at 45 psi pressure using $5 \% \mathrm{Pd}$ on activated carbon gave the partially reduced vinylogous amide 12 in $80 \%$ yield. ${ }^{12 a}$ Deprotonation of $\mathbf{1 2}$ by LiHMDS and treatment of the resulting anion with $\mathrm{ClCO}_{2} \mathrm{Me}$ afforded the vinylogous imide 13 in $85 \%$ yield. Finally, deprotonation of the ketone using KHMDS followed by $O$-silylation with TBSCl gave the $N$-carbomethoxy siloxy diene 7 in $98 \%$ yield. The Diels-Alder reaction of diene 7 with 2-bromoacrolein, when performed at room temperature in dry $\mathrm{CH}_{2} \mathrm{Cl}_{2}$, was found to proceed smoothly in the absence of a catalyst to yield the cycloadduct in a 15:1 diastereomeric ratio (Scheme 3). However, rather than the expected Diels-Alder adduct 11, oxazolidinone 14 was the major product of this reaction. Subsequent reduction of the aldehyde using $\mathrm{NaBH}_{4}$ followed by the protection of the resulting primary alcohol with $\mathrm{TBSCl} /$ imidazole gave silyl enol ether 15 in $48 \%$ isolated yield over three steps. Alternatively, further elaboration of the DielsAlder adduct through a Wittig-Levine homologation provided the enol-ether as a 1.4:1 mixture of isomers in $72 \%$ yield, which on treatment with TBAF removed the silyl ether to reveal ketone 16. ${ }^{13}$ Formation of the unexpected oxazolidinone can be rationalized as proposed in Scheme 3. The initial Diels- 
Alder reaction is expected to give the endo cycloadduct $\mathbf{1 1}$ based on previous examples with related dienes and dienophiles. $^{8 c, d}$ Subsequent intramolecular attack of the electron-rich carbamate oxygen on the $\alpha$-carbon of the aldehyde would displace $\mathrm{Br}^{-}$and form methylated oxazolidinone 17. Finally, demethylation by the nucleophilic attack of $\mathrm{Br}^{-}$anion would furnish the neutral oxazolidinone 14 . Although $\mathrm{S}_{\mathrm{N}} 2$ reactions of $3^{\circ}$-alkyl halides are generally not favorable due to steric reasons, the intramolecular nature of the present reaction, particularly the enforced proximity of the Lewis basic carbamate oxygen to the reaction center, the ultimate formation of a 5-membered ring, and the increased electrophilicity of the alkyl bromide due to the presence of the neighboring aldehyde might account for the facility of this transformation. The direct conversion of the initial DA adduct $\mathbf{1 1}$ to oxazolidinone $\mathbf{1 4}$ could not be prevented even by running the reaction at low temperature $\left(-78{ }^{\circ} \mathrm{C}\right)$. As such, the initial retrosynthetic analysis was modified slightly to include oxazolidinone $\mathbf{1 4}$ rather than the bromide $\mathbf{1 1}$.

We had shown in the past that the Diels-Alder reactions of carbamate siloxy dienes could be rendered enantioselective by the use of chiral $\mathrm{Cr}$ (III) - and $\mathrm{Co}$ (III)-salen complexes as catalysts. ${ }^{8}$ Although in those studies we had not examined a diene as elaborate as 7 , consideration of the transition state that we had proposed for the observed enantioselectivity suggested that diene 7 could be a successful partner for the salen catalyzed cycloaddition. Indeed, when the Diels-Alder reaction between 6 and 7 was run at $-78{ }^{\circ} \mathrm{C}$ in the presence of $\mathrm{Co}-$ salen catalyst $18(10 \mathrm{~mol} \%)$, the desired product (15) was obtained with 94\% ee and a dr of $>15: 1$ after reduction and TBS protection (63\% yield over three steps, Scheme 4). This reaction was carried out successfully on gramscale.

\section{Scheme 4. Enantioselective Diels-Alder Reaction of Diene 7}

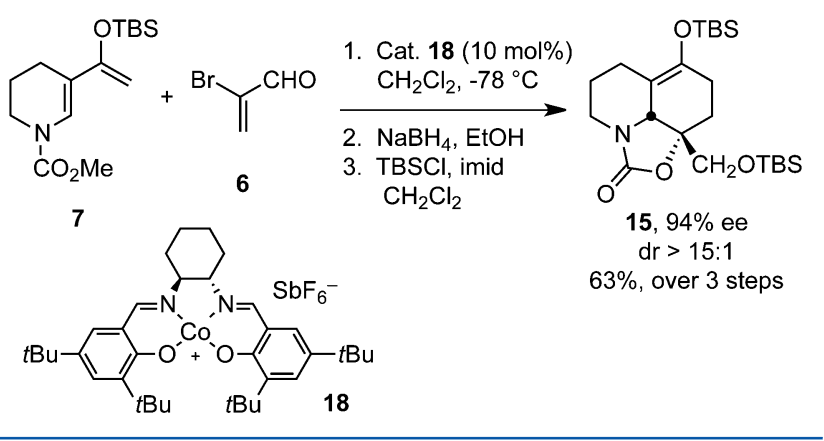

Having established routes that provide efficient access to the cycloadducts through racemic and enantioselective Diels-Alder chemistry, we then used the racemic product to explore methods for introduction of the aniline component, as required in intermediate 10 (Scheme 2). Introduction of unsaturation in the core of the molecule (ketone 16), to allow installation of the aniline through a Michael reaction, proved more challenging than expected. Attempted use of LDA as a base for kinetic deprotonation followed by selenation with $\mathrm{PhSeCl}$ and selenoxide elimination gave primarily the starting ketone, but with the oxazolidinone having been fragmented, along with a small amount of an enone in which the double bond was inside the piperidine ring, indicative of deprotonation and selenation of the more substituted side. Deprotonation with the more hindered LiHMDS left the carbamate untouched, and upon selenation and oxidative elimination afforded a $1: 1$ mixture of regioisomeric enones, tentatively assigned as 19 and 20 (eq 1 ).

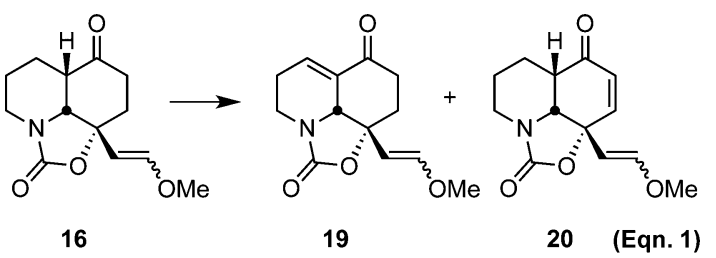

Given the complications observed with ketone 16, attention was directed at the elaboration of silyl enol ether 15. Treatment of 15 with trifluoroacetic acid cleanly afforded ketone 21 with a cis ring fusion (Scheme 5). Remarkably, deprotonation of $\mathbf{2 1}$

Scheme 5. Regioselective Allylation of Ketone 21

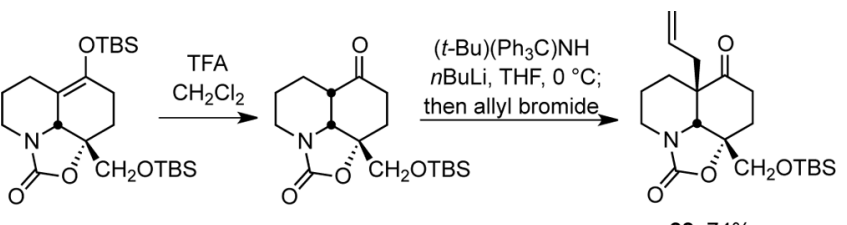

15

21 22, $74 \%$

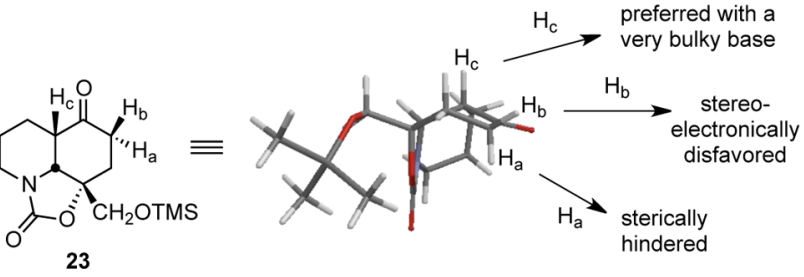

with the extremely bulky base $(t-\mathrm{Bu})\left(\mathrm{Ph}_{3} \mathrm{C}\right) \mathrm{NLi}^{14}$ followed by the reaction of the resulting enolate with allyl bromide allowed the formation of the needed quaternary center with ketone $\mathbf{2 2}$ being isolated in $74 \%$ yield over two steps. Initially, the relative configuration of this product was assigned through the nuclear Overhauser effect (NOE) correlations obtained from its NOESY spectrum. This assignment was later confirmed unequivocally through the X-ray crystallographic analysis of a more advanced intermediate (compound 30, see below). Finally, it is worth mentioning that the use of $(t-\mathrm{Bu})\left(\mathrm{Ph}_{3} \mathrm{C}\right) \mathrm{NLi}$ was crucial for the success of this transformation as less bulky bases such as LiHMDS or LiTMP were found to give a ca. 1:1 mixture of regioisomeric enolates, as noted for ketone $\mathbf{1 6}$.

At first glance, these observations seem untenable, given that the bulkier base has promoted formation of the enolate from the sterically more hindered position. However, this counterintuitive situation can be better understood by considering the conformation of the molecule in conjunction with the steric and stereoelectronic requirements for enolate formation. The energy-minimized structure ${ }^{15}$ of the TMS-protected analogue 23 is shown in Scheme 5. While $\mathrm{H}_{\mathrm{b}}$ appears to be sterically the most accessible proton for enolate formation, its abstraction is stereoelectronically disfavored due to the poor alignment of the $\sigma$-bond of the $\mathrm{C}-\mathrm{H}$ with the $\mathrm{C}=\mathrm{O} \pi^{*}$ orbital. On the other hand, $\mathrm{H}_{a}$, which is more properly oriented for deprotonation, is shielded from the base, especially a very bulky base, as it is positioned in the concave region of the tricyclic framework. Finally, even though $\mathrm{H}_{c}$ is situated on a tertiary carbon, it is positioned on the convex face of the molecule, and its abstraction is stereoelectronically favored (better $\sigma_{\mathrm{C}-\mathrm{H}}-\pi^{*}{ }_{\mathrm{C}=\mathrm{O}}$ 
overlap). The above rationale may explain the surprising observation that deprotonation by a bulky base is favored at the more substituted position of bicyclic ketone 21 .

We next investigated the oxidation of ketone $\mathbf{2 2}$ to enone $\mathbf{2 4}$ (Scheme 6). After an extensive screening of the common

\section{Scheme 6. Intramolecular Aza-Michael Reaction}
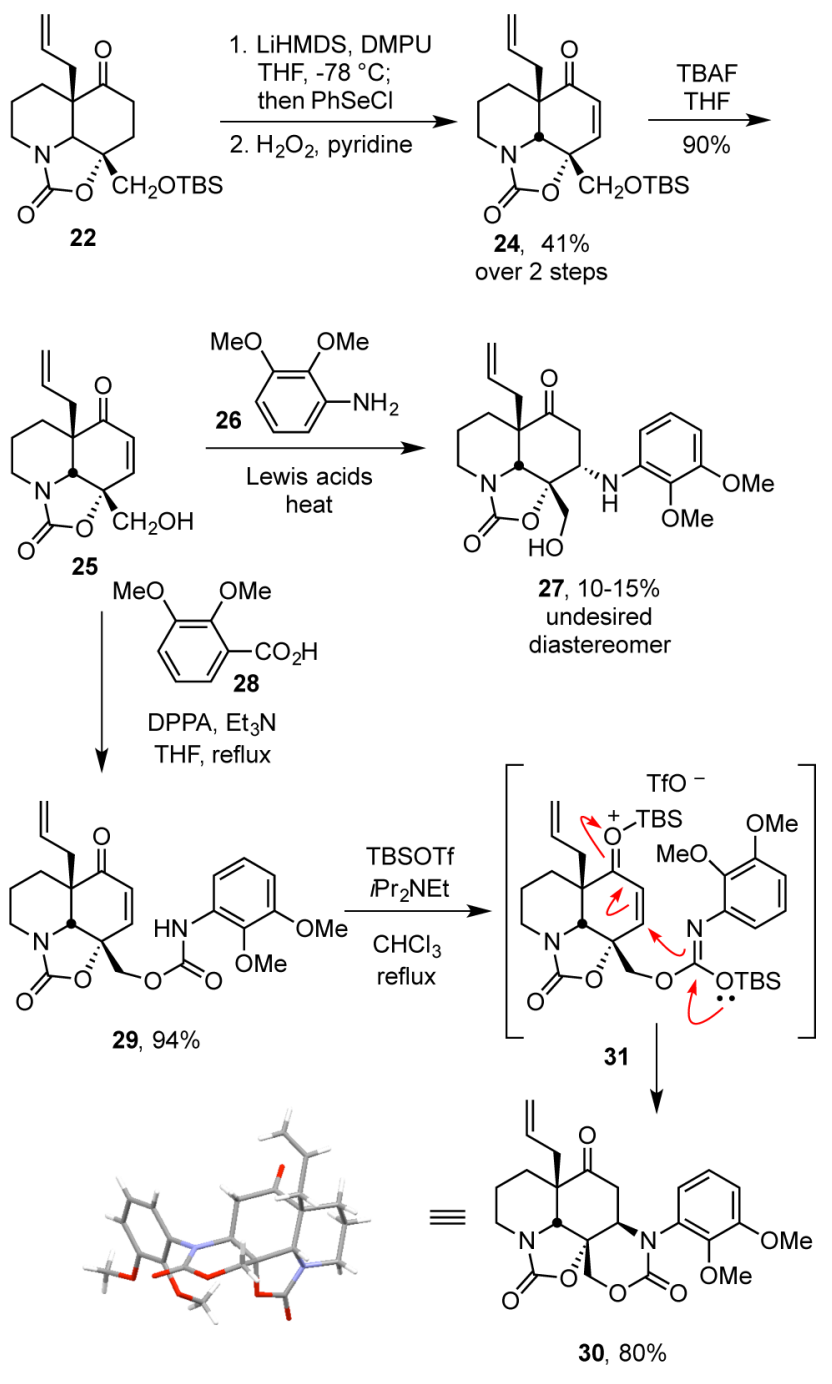

methods available for this transformation, we found the selenoxide elimination method to be the highest yielding. ${ }^{16}$ Formation of the enolate with LiHMDS in a mixture of DMPU and THF and its subsequent treatment with $\mathrm{PhSeCl}$ gave the $\alpha$ selenylated product with a $\mathrm{dr}$ of 10:3. Oxidation of this intermediate with $\mathrm{H}_{2} \mathrm{O}_{2}$ followed by elimination of $\mathrm{PhSeOH}$ afforded enone 24 in $41 \%$ yield over two steps. It should be noted that this reaction was performed using $3.81 \mathrm{~g}$ of ketone 22 and afforded a useful amount $(1.56 \mathrm{~g})$ of the enone product. The deprotection of the TBS-protected alcohol proceeded uneventfully and provided the free alcohol 25 in $90 \%$ yield. Similar to the above case, this step was also performed on gramcale $(1.56 \mathrm{~g}$ of 24$)$ and afforded the free alcohol product in $87 \%$ yield ( $0.95 \mathrm{~g}$ of $\mathbf{2 5})$.

With enone 25 in hand, we next sought to perform the azaMichael reaction that would form the $\mathrm{C}-\mathrm{N}$ bond required for construction of the indoline unit (Scheme 6). For this purpose, 2,3-dimethoxyaniline (26) was prepared in two steps from 2,3dimethoxybenzoic acid, following a reported procedure. ${ }^{17}$ First, the uncatalyzed reaction between enone 25 and aniline 26 was tested. However, when the reaction was carried out in $\mathrm{CH}_{3} \mathrm{CN}$ (room temperature, then $80{ }^{\circ} \mathrm{C}$ ) or in $\mathrm{CH}_{3} \mathrm{OH}$ (room temperature, then $60{ }^{\circ} \mathrm{C}$ ), none or only trace amounts of the conjugate addition product were obtained. Lewis acid catalyzed intermolecular aza-Michael reactions of amine and aniline derivatives with $\alpha, \beta$-unsaturated carbonyl compounds have been investigated extensively, and several of the reported conditions were investigated. ${ }^{18}$ Among the different Lewis acids examined as catalysts for this reaction, the most promising result was obtained when a mixture of $\mathbf{2 5}$ and excess 2,3dimethoxyaniline (26) in the presence of $\mathrm{ZrOCl}_{2} \cdot 8 \mathrm{H}_{2} \mathrm{O}^{19}$ was heated at $110{ }^{\circ} \mathrm{C}$ for $24 \mathrm{~h}$, which provided the aza-Michael product 27 in $13 \%$ yield along with $60 \%$ recovered enone. Disappointingly, this aza-Michael product was later determined to be the undesired diastereomer, formed through the attack of the aniline derivative from the $\alpha$-face of the enone.

To overcome formation of the undesired diastereomer, we explored the use of an intramolecular cyclization strategy. ${ }^{20}$ Such an aza-Michael addition was expected not only to give the correct configuration but also to be more favorable based on entropic considerations. Initial attempts using silicon and aminal tethers to achieve this goal proved to be unfruitful. Attention was then directed to the utilization of a carbamate tether to deliver the nucleophile. The tethering was achieved by heating a mixture of 25, 2,3-dimethoxybenzoic acid (28), $\mathrm{DPPA}^{21}$ and $\mathrm{Et}_{3} \mathrm{~N}$ in refluxing THF, which gave the carbamate product 29 in $94 \%$ isolated yield (Scheme 6). We next sought to investigate the key intramolecular aza-Michael reaction. Unfortunately, basic conditions using $\mathrm{NaH}$, KHMDS (catalytic or stoichiometric amounts), or KHMDS/18-crown-6 did not give any desired cyclization product. ${ }^{22}$ We were delighted to see, however, that the cyclic carbamate $\mathbf{3 0}$ was obtained in $80 \%$ isolated yield when the reaction was carried out using TBSOTf and Hunig's base $\left(i-\mathrm{Pr}_{2} \mathrm{NEt}\right)$ in refluxing $\mathrm{CHCl}_{3}$. It is likely that the carbamate reacts with TBSOTf in the presence of Hunig's base to form the $O$-silyl imidate intermediate (31). Additional TBSOTf can silylate the enone carbonyl, which would promote an aza-Michael reaction by the imidate nitrogen, so as to give the desired product $\mathbf{3 0}$, after desilylation during hydrolytic workup. The structure of the cyclic carbamate $\mathbf{3 0}$ was established unequivocally through ${ }^{1} \mathrm{H}$ and ${ }^{13} \mathrm{C}$ NMR, HRMS, and X-ray crystallographic analysis. The crystal structure also confirmed the relative stereochemical assignments of the previous intermediates.

We next investigated the hydrolysis of the six-membered cyclic carbamate moiety of $\mathbf{3 0}$ to afford the desired amino alcohol product 32 (Scheme 7). This transformation is fraught with complications, as there are two different carbamates in $\mathbf{3 0}$, one a five-membered ring, an oxazolidinone unit, and the other a six-membered ring carbamate that is succeptible to a retroMichael reaction. A noteworthy aspect of the latter is that the amine component is an aniline derivative, which would render the carbonyl carbon of this carbamate more electron-deficient and hence more susceptible to nucleophiles. This anticipated higher reactivity, in particular, suggested that it might be possible to accomplish selective hydrolysis of the six-membered ring carbamate over the five-membered one. The above rationale notwithstanding, the hydrolysis step proved quite challenging. Under basic conditions, using $\mathrm{LiOH}$ in $\mathrm{THF} / \mathrm{H}_{2} \mathrm{O}$ or $\mathrm{LiOH} / \mathrm{LiCl}$ in $\mathrm{MeOH}$, only the retro-aza-Michael reaction was observed, and the open carbamate 29 was obtained as the sole product. On the other hand, acidic conditions using 
Scheme 7. Conversion of Carbamate 30 to Amino Alcohol 32
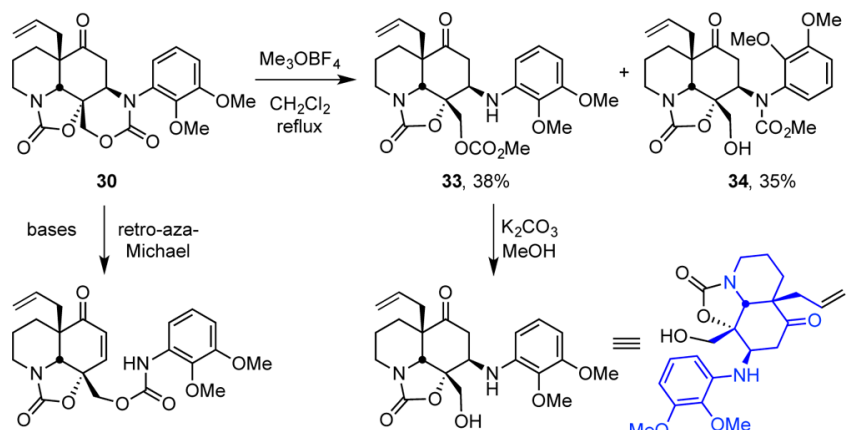

29

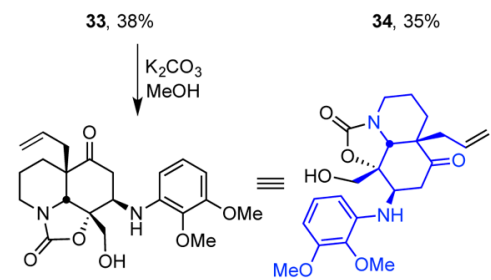

$32,96 \%$

TMSCl in $\mathrm{MeOH}$ (room temperature, then $50{ }^{\circ} \mathrm{C}$ ), $\mathrm{HCl}$ in $\mathrm{EtOH} / \mathrm{H}_{2} \mathrm{O}$, or $\mathrm{TsOH}$ in $\mathrm{MeOH}$ (room temperature, then 60 ${ }^{\circ} \mathrm{C}$ ) gave no reaction. In addition, when $\mathbf{3 0}$ was treated with TMSBr in $\mathrm{CH}_{2} \mathrm{Cl}_{2}$ at room temperature and at $40{ }^{\circ} \mathrm{C}$, no reaction was observed, and the starting material was returned intact. We were delighted to find, however, that treatment of $\mathbf{3 0}$ with Meerwein's salt ${ }^{23}\left(\mathrm{Me}_{3} \mathrm{OBF}_{4}\right)$ in refluxing $\mathrm{CH}_{2} \mathrm{Cl}_{2}$ followed by aqueous workup gave isomeric carbonate 33 and carbamate 34 in $38 \%$ and $35 \%$ yields, respectively (Scheme 7). The hydrolysis of the carbonate group of 33 using $\mathrm{K}_{2} \mathrm{CO}_{3}$ in $\mathrm{MeOH}$ afforded the amino alcohol product 32 in $96 \%$ yield.

Finally, with amino alcohol 32 in hand, we investigated its oxidation to aldehyde 35, which could be further elaborated through Wittig-Levine olefination followed by a FriedelCrafts cyclization to give the desired indoline. Surprisingly, when 32 was treated with Dess-Martin periodinane (DMP) ${ }^{24}$ in $\mathrm{CH}_{2} \mathrm{Cl}_{2}$ at room temperature, ketone 36 was obtained in $49 \%$ yield as the major product (Scheme 8 ). Compound 36 has

\section{Scheme 8. Conversion of Alcohol 32 to Ketone 36}<smiles>C=CC[C@@]12CCCN3C(=O)C[C@@](CO)([C@H]1Nc1cccc(OC)c1OC)[C@@H]2OC3=O</smiles>

32

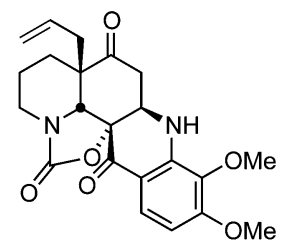

36, $49 \%$
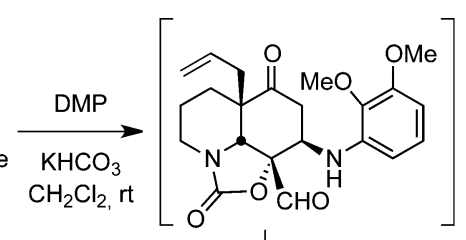

35

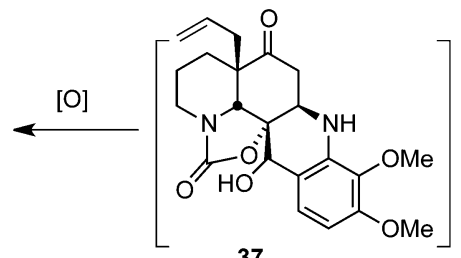

37

a bright yellow color, presumably due to the electronic pushpull system generated by the $o$-aminoacetophenone moiety. The formation of this unexpected product is the consequence of three successive reactions. The initial oxidation of alcohol 32 evidently generates aldehyde 35, which then undergoes an intramolecular Friedel-Crafts type cyclization to give rise to 37 with formation of a six-membered ring. Further oxidation of the alcohol can then afford the observed ketone 36. Unfortunately, despite several different conditions examined, including a variety of oxidants [inter alia, TPAP/NMO and TEMPO/
$\left.\mathrm{PhI}(\mathrm{OAc})_{2}\right]$, the oxidation could not be stopped after only the first stage, to allow isolation of aldehyde 35 as the major product. For example, the effects of the amount of the oxidant, reaction time, and the presence of pyridine as a buffering reagent on the reaction outcome were investigated, but to little avail. By limiting the amount of the oxidant, it was possible to isolate a small amount of alcohol 37 , with even less of aldehyde 35 , but this method did not provide a usable solution to the problem. What oxidation attempts clearly demonstrated is that the electron-rich aniline will readily participate in a FriedelCrafts cyclization, and this understanding will help shape the development of a revised endgame to aspidophytine.

\section{CONCLUSIONS}

In summary, we have developed an efficient, stereocontrolled route for the synthesis of the perhydroquinoline core of the indole alkaloid aspidophytine (2). The key Diels-Alder reaction of carbamate siloxy diene 7 with 2-bromoacrolein (6) proceeded smoothly to give a cycloadduct that underwent a spontaneous intramolecular substitution reaction between the newly formed $3^{\circ}$-alkyl bromide and the carbamate group. Importantly, this central cycloaddition can be rendered enantioselective by the use of the chiral $\mathrm{Co}$ (III)-salen catalyst 18 to afford compound $\mathbf{1 5}$ in $94 \%$ ee. The electron-rich aniline moiety was installed via a TBSOTf-mediated intramolecular aza-Michael reaction, and the relative configuration of the product (30) was established by X-ray crystallographic analysis. Finally, initial studies to oxidize the primary alcohol group in $\mathbf{3 2}$ led to the formation of ketone 36 via a series of reactions including an intramolecular Friedel-Crafts type cyclization between the electron-rich aniline and the newly formed aldehyde. While key elements of the strategy have proven effective, the rapidity of the unwanted cyclization reaction will necessitate revision of the endgame of the synthesis, and results from those studies will be reported in due course.

\section{EXPERIMENTAL SECTION}

General Information. All air-sensitive reactions were performed using oven-dried glassware under $\mathrm{N}_{2}$ or $\mathrm{Ar}$ atmosphere. Reactions were monitored by TLC on silica gel $60 \AA$ F 254 plates visualized by $\mathrm{UV}$ and $\mathrm{KMnO}_{4}$ or Hanessian's staining solutions. Flash column chromatography was performed on 32-63 $\mu \mathrm{m}$ flash silica gel. NMR spectra were measured at $500 \mathrm{MHz}$ for ${ }^{1} \mathrm{H}$ spectra and $125 \mathrm{MHz}$ for ${ }^{13} \mathrm{C}$ spectra and calibrated from residual solvent signals (chloroform at $7.26 \mathrm{ppm}$ and DMSO at $2.50 \mathrm{ppm}$ for ${ }^{1} \mathrm{H}$ spectra; chloroform at 77.0 $\mathrm{ppm}$ and DMSO at $39.51 \mathrm{ppm}$ for ${ }^{13} \mathrm{C}$ spectra). Infrared spectra were measured on $\mathrm{NaCl}$ plates. Melting points are uncorrected. Highresolution mass spectra (ESI) were obtained using an ion trap mass analyzer.

Dichloromethane $\left(\mathrm{CH}_{2} \mathrm{Cl}_{2}\right)$, toluene, and tetrahydrofuran (THF) were purified by passage over activated alumina using a commercial solvent purification system. Hunig's base $\left(i \mathrm{Pr}_{2} \mathrm{NEt}\right)$ was distilled under nitrogen and stored at $0{ }^{\circ} \mathrm{C}$ over $\mathrm{KOH}$ pellets.

Methyl 5-(1-((tert-Butyldimethylsilyl)oxy)vinyl)-3,4-dihydropyridine-1 $(2 \mathrm{H})$-carboxylate (7). A solution of vinylogous imide 13 (668 mg, $3.65 \mathrm{mmol}$ ) in $5 \mathrm{~mL}$ of anhydrous THF was added dropwise over $10 \mathrm{~min}$ to a solution of KHMDS $(8.75 \mathrm{~mL}, 0.5 \mathrm{M}$ in toluene, 4.38 $\mathrm{mmol})$ in THF $(10 \mathrm{~mL})$ at $-78{ }^{\circ} \mathrm{C}$. The resulting solution was warmed to $-55^{\circ} \mathrm{C}$ over $1 \mathrm{~h}$ and then cooled to $-78^{\circ} \mathrm{C}$. A solution of TBSCl $(659 \mathrm{mg}, 4.38 \mathrm{mmol})$ in $5 \mathrm{~mL}$ of THF was added dropwise, and the reaction mixture was warmed to room temperature over $2 \mathrm{~h}$. The suspension was filtered through Celite, rinsed with $\mathrm{Et}_{2} \mathrm{O}$, and then concentrated in vacuo to a yellow oil. Kugelrohr bulb-to-bulb distillation $\left(225{ }^{\circ} \mathrm{C}, 0.3 \mathrm{mmHg}\right)$ afforded pure diene 7 (1.06 g, $98 \%)$ as a pale yellow oil: ${ }^{1} \mathrm{H} \mathrm{NMR}\left(400 \mathrm{MHz}, \mathrm{CDCl}_{3}\right) \delta 7.50-7.38$ 
(m, 1H), $4.25(\mathrm{~s}, 1 \mathrm{H}), 4.17(\mathrm{~s}, 1 \mathrm{H}), 3.76(\mathrm{~s}, 3 \mathrm{H}), 3.60-3.53(\mathrm{~m}, 2 \mathrm{H})$, 2.19-2.15 (m, 2H), 1.90-1.81 (m, 2H), $0.99(\mathrm{~s}, 9 \mathrm{H}), 0.18(\mathrm{~s}, 6 \mathrm{H})$; ${ }^{13} \mathrm{C} \mathrm{NMR}\left(100 \mathrm{MHz}, \mathrm{CDCl}_{3}\right) \delta 155.6,154.1,123.8,114.3,89.1,53.2$, 41.9, 25.9, 21.9, 21.3, 18.3, -4.5; IR (film) 2955, 2858, 1716, 1647, 1260, $1129 \mathrm{~cm}^{-1}$; MS (CI Pos) calcd for $\mathrm{C}_{15} \mathrm{H}_{28} \mathrm{NO}_{3} \mathrm{Si}$ 298.1, found 298.1 .

( \pm$)-\left(3^{1} R, 9 a S\right)-7-(($ tert-Butyldimethylsilyl)oxy)-9a-((tertbutyldimethylsilyl)oxy)methyl)-3 ${ }^{1}, 5,6,8,9,9 a-h e x a h y d r o-$ $2 \mathrm{H}, 4 \mathrm{H}$-oxazolo[5,4,3-ij]quinolin-2-one (15). To a stirred solution of diene $7(3.79 \mathrm{~g}, 12.7 \mathrm{mmol})$ in $25 \mathrm{~mL}$ of anhydrous $\mathrm{CH}_{2} \mathrm{Cl}_{2}$ was added a solution of 2-bromoacrolein $6(1.89 \mathrm{~g}, 14.0 \mathrm{mmol})$ in $10 \mathrm{~mL}$ of $\mathrm{CH}_{2} \mathrm{Cl}_{2}$ dropwise, at room temperature, under nitrogen. The reaction was observed to be exothermic. The resulting mixture was stirred for $2 \mathrm{~h}$, at which time additional 2-bromoacrolein $(0.24 \mathrm{~g}, 1.8$ $\mathrm{mmol}$ ) was added. At the end of $3 \mathrm{~h}$, all volatiles were evaporated in vacuo to afford the crude Diels-Alder cycloadduct as a yellow oil $(\mathrm{dr}=$ 15:1 by ${ }^{1} \mathrm{H}$ NMR analysis).

The crude product was dissolved in $30 \mathrm{~mL}$ of anhydrous $\mathrm{EtOH}$ and cooled to $0{ }^{\circ} \mathrm{C} . \mathrm{NaBH}_{4}(722 \mathrm{mg}, 19.1 \mathrm{mmol})$ was added portionwise, and the resulting mixture was stirred at $0{ }^{\circ} \mathrm{C}$ for $20 \mathrm{~min}$ and at room temperature overnight. It was then quenched with saturated $\mathrm{NaHCO}_{3}$ solution, causing gas evolution. The mixture was stirred for $30 \mathrm{~min}$, diluted with $\mathrm{CH}_{2} \mathrm{Cl}_{2}$, and filtered by suction. The aqueous phase was extracted four times with $\mathrm{CH}_{2} \mathrm{Cl}_{2}$, and the combined organic phase was dried over $\mathrm{MgSO}_{4}$. Filtration and concentration in vacuo afforded crude alcohol product $(3.82 \mathrm{~g})$ as a light yellow solid.

The crude alcohol $(3.03 \mathrm{~g})$ was dissolved in $25 \mathrm{~mL}$ of anhydrous $\mathrm{CH}_{2} \mathrm{Cl}_{2}$, and imidazole $(1.82 \mathrm{~g}, 26.7 \mathrm{mmol})$ was added at room temperature, under nitrogen. A solution of $\mathrm{TBSCl}(1.61 \mathrm{~g}, 10.7 \mathrm{mmol})$ in $5 \mathrm{~mL}$ of $\mathrm{CH}_{2} \mathrm{Cl}_{2}$ was then added slowly, and the reaction mixture was stirred for 2 days at room temperature. It was then quenched with $\mathrm{H}_{2} \mathrm{O}$, and the aqueous phase was extracted four times with $\mathrm{CH}_{2} \mathrm{Cl}_{2}$. The combined organic phase was dried over $\mathrm{MgSO}_{4}$, filtered, and concentrated in vacuo to afford a yellow oil. Purification by flash column chromatography (EtOAc/hexanes 1:7) gave pure 15 (2.22 g, $48 \%$ over three steps) as a white solid.

Catalysis of the Enantioselective Diels-Alder Reaction by Co(III)-salen Catalyst 18. A solution of diene $7(1.87 \mathrm{~g}, 6.27 \mathrm{mmol})$ in $10 \mathrm{~mL}$ of $\mathrm{CH}_{2} \mathrm{Cl}_{2}$ was added slowly to a cooled $\left(-78^{\circ} \mathrm{C}\right)$ solution of catalyst $18^{8 \mathrm{~d}}(526 \mathrm{mg}, 0.63 \mathrm{mmol})$ in $\mathrm{CH}_{2} \mathrm{Cl}_{2}(40 \mathrm{~mL})$. A solution of 2-bromoacrolein $6(1.95 \mathrm{~g}, 14.4 \mathrm{mmol})$ in $\mathrm{CH}_{2} \mathrm{Cl}_{2}(10 \mathrm{~mL})$ was then added dropwise over $30 \mathrm{~min}$. The resulting solution was stirred at $-78{ }^{\circ} \mathrm{C}$ for $2.5 \mathrm{~h}$ and then concentrated in vacuo to a black oil. The crude product was co-concentrated with $\mathrm{CH}_{2} \mathrm{Cl}_{2}(3 \times 50 \mathrm{~mL})$ to remove any remaining bromomethane. The crude aldehyde was dissolved in $60 \mathrm{~mL}$ of ethanol and cooled to $0{ }^{\circ} \mathrm{C} . \mathrm{NaBH}_{4}(356 \mathrm{mg}$, $9.41 \mathrm{mmol}$ ) was carefully added in portions, and the resulting brown mixture was stirred at room temperature for $20 \mathrm{~min}$. Brine $(60 \mathrm{~mL})$ and $\mathrm{Et}_{2} \mathrm{O}(100 \mathrm{~mL})$ were then added carefully. The organic layer was washed three times with $\mathrm{H}_{2} \mathrm{O}$, dried over $\mathrm{MgSO}_{4}$, and then filtered and concentrated in vacuo. The crude product was dissolved in $\mathrm{CH}_{2} \mathrm{Cl}_{2}$ $(60 \mathrm{~mL})$ and treated with imidazole $(854 \mathrm{mg}, 12.5 \mathrm{mmol})$ and TBSCl $(1.42 \mathrm{~g}, 9.41 \mathrm{mmol})$ sequentially at room temperature. The reaction mixture was stirred for $16 \mathrm{~h}$, and then $\mathrm{H}_{2} \mathrm{O}(50 \mathrm{~mL})$ was added. The aqueous layer was extracted three times with $\mathrm{CH}_{2} \mathrm{Cl}_{2}$, and the combined organic layers were dried over $\mathrm{MgSO}_{4}$, filtered, and concentrated in vacuo to a brown oil. Purification by flash column chromatography (10\% EtOAc in hexanes) gave 15 (1.78 g, 63\% over three steps, $94 \%$ ee) as a brown oil: ${ }^{1} \mathrm{H}$ NMR $\left(500 \mathrm{MHz}, \mathrm{CDCl}_{3}\right) \delta$ $3.88(\mathrm{~s}, 1 \mathrm{H}), 3.85(\mathrm{dd}, J=13.5,5.0 \mathrm{~Hz}, 1 \mathrm{H}), 3.68(\mathrm{~d}, J=10.3 \mathrm{~Hz}, 1 \mathrm{H})$, $3.54(\mathrm{~d}, J=10.3 \mathrm{~Hz}, 1 \mathrm{H}), 2.99-2.93(\mathrm{~m}, 2 \mathrm{H}), 2.30-2.25(\mathrm{~m}, 1 \mathrm{H})$, 2.05-1.99 (m, 2H), 1.97-1.92 (m, 1H), 1.70-1.64 (m, 2H), 1.53$1.43(\mathrm{~m}, 1 \mathrm{H}), 0.93(\mathrm{~s}, 9 \mathrm{H}), 0.88(\mathrm{~s}, 9 \mathrm{H}), 0.13(\mathrm{~s}, 3 \mathrm{H}), 0.12(\mathrm{~s}, 3 \mathrm{H})$, $0.06(\mathrm{~s}, 6 \mathrm{H}) ;{ }^{13} \mathrm{C}$ NMR $\left(125 \mathrm{MHz}, \mathrm{CDCl}_{3}\right) \delta 156.8,143.9,110.3$, $79.0,65.8,57.6,41.9,26.6,26.1,25.83,25.76,25.6,24.0,18.2,18.1$, $-3.7,-4.0,-5.48,-5.51$; IR (film) 2954, 2930, 2857, 1761, 1688, $1367,1254,1107,839 \mathrm{~cm}^{-1}$; HRMS (ESI) calcd for $\left(\mathrm{C}_{23} \mathrm{H}_{43} \mathrm{NO}_{4} \mathrm{Si}_{2}\right)$ $\mathrm{Na}^{+}(\mathrm{M}+\mathrm{Na})^{+}$476.2623, found 476.2626; HPLC: OD-H, 98\% hexanes, $2 \%$ i-PrOH, $0.8 \mathrm{~mL} / \mathrm{min}, 7.4 \mathrm{~min}$ (minor), $8.2 \mathrm{~min}$ (major).
( \pm )-( $\left.3^{1} R, 6 \mathrm{a} S, 9 \mathrm{a} S\right)-9 \mathrm{a}-((($ tert-Butyldimethylsilyl)oxy)methyl)octahydro-2H,7H-oxazolo[5,4,3-ij] quinoline-2,7-dione (21). To a solution of the silyl enol ether $15(1.726 \mathrm{~g}, 3.8 \mathrm{mmol})$ in $12 \mathrm{~mL}$ of anhydrous $\mathrm{CH}_{2} \mathrm{Cl}_{2}$ was added trifluoroacetic acid (TFA, $0.88 \mathrm{~mL}, 11.4$ $\mathrm{mmol}$ ) at room temperature, under nitrogen. The color of the solution first turned brown-red and then pink as the reaction proceeded. After 1 $h$, the reaction mixture was quenched with saturated $\mathrm{NaHCO}_{3}$ solution and turned yellow with evolution of gas. The aqueous phase was extracted three times with $\mathrm{CH}_{2} \mathrm{Cl}_{2}$. The combined organic phase was dried over $\mathrm{MgSO}_{4}$, filtered, and concentrated in vacuo to afford a yellow oil, which solidified upon standing in the refrigerator to give 21 a yellow-white solid $(1.282 \mathrm{~g})$. The crude product was clean enough to be used directly in the next step. Purification of a portion of the crude product by flash column chromatography (EtOAc/hexanes $1: 4$ to $1: 3$ to $1: 2$ ) gave analytically pure ketone 21 as a white solid: ${ }^{1} \mathrm{H}$ NMR $\left(500 \mathrm{MHz}, \mathrm{CDCl}_{3}\right) \delta 3.95(\mathrm{~d}, J=4.7,1 \mathrm{H}), 3.80-3.76(\mathrm{~m}, 1 \mathrm{H})$, $3.72(\mathrm{~d}, J=10.4 \mathrm{~Hz}, 1 \mathrm{H}), 3.63(\mathrm{~d}, J=10.4 \mathrm{~Hz}, 1 \mathrm{H}), 2.77(\mathrm{dt}, J=12.7$, $3.7 \mathrm{~Hz}, 1 \mathrm{H}), 2.57-2.52(\mathrm{~m}, 1 \mathrm{H}), 2.47-2.35(\mathrm{~m}, 3 \mathrm{H}), 2.09(\mathrm{dt}, J=$ 14.7, $5.5 \mathrm{~Hz}, 1 \mathrm{H}), 2.01(\mathrm{dq}, J=14.8,2.7 \mathrm{~Hz}, 1 \mathrm{H}), 1.48-1.34(\mathrm{~m}, 3 \mathrm{H})$, 0.85 (s, 9H), $0.06(\mathrm{~s}, 6 \mathrm{H}) ;{ }^{13} \mathrm{C}$ NMR $\left(125 \mathrm{MHz}, \mathrm{CDCl}_{3}\right) \delta 209.3$, 155.1, 79.7, 67.4, 57.5, 43.6, 40.7, 33.7, 26.3, 25.6, 22.5, 19.9, 18.0, -5.6; IR (film) 2953, 2930, 2857, 1751, 1716, 1436, 1258, 1137, 1120, $1095,1052,839 \mathrm{~cm}^{-1}$; HRMS (ESI) Calcd for $\left(\mathrm{C}_{17} \mathrm{H}_{29} \mathrm{NO}_{4} \mathrm{Si}\right) \mathrm{Na}^{+}(\mathrm{M}$ $+\mathrm{Na})^{+} 362.1758$, found 362.1750 .

( \pm$)-\left(3^{1} R, 6 \mathrm{a} R, 9 \mathrm{a} S\right)-6 \mathrm{a}-A l l y l-9 \mathrm{a}-((($ tert-butyldimethylsilyl)oxy)methyl)octahydro-2H,7H-oxazolo[5,4,3-ij]quinoline-2,7-dione (22). $t$ - $\mathrm{Bu}\left(\mathrm{Ph}_{3} \mathrm{C}\right) \mathrm{NH}(1.142 \mathrm{~g}, 3.62 \mathrm{mmol})$ was dissolved in $7 \mathrm{~mL}$ of anhydrous THF in a flask containing $4 \AA$ molecular sieves, and the resulting solution was transferred to an oven-dried, $50 \mathrm{~mL}$ Schlenk flask under nitrogen. The solution was cooled to $0{ }^{\circ} \mathrm{C}$, and $n$-BuLi $(1.50 \mathrm{~mL}, 3.47 \mathrm{mmol}, 2.3 \mathrm{M}$ in hexanes) was added dropwise. The resulting orange-brown mixture was stirred at $0{ }^{\circ} \mathrm{C}$ for $1 \mathrm{~h}$, and then a solution of ketone 21 (1.069 g, $3.15 \mathrm{mmol})$ in $11 \mathrm{~mL}$ of anhydrous THF was added dropwise over $10 \mathrm{~min}$. Within a short time, the color turned light brown-orange, and the reaction mixture was stirred at room temperature for $2 \mathrm{~h}$. Allyl bromide $(410 \mu \mathrm{L}, 4.73 \mathrm{mmol})$ was then added, and the reaction was allowed to proceed for $17 \mathrm{~h}$. It was then quenched with $\mathrm{H}_{2} \mathrm{O}$, and the aqueous phase was extracted four times with $\mathrm{CH}_{2} \mathrm{Cl}_{2}$. The combined organic phase was dried over $\mathrm{MgSO}_{4}$, filtered, and concentrated in vacuo to afford a brown oil. Purification by flash column chromatography (EtOAc/hexanes, 1:2) gave pure ketone 22 ( $888 \mathrm{mg}, 74 \%$ over two steps) as a light yellow oil: ${ }^{1} \mathrm{H}$ NMR $\left(500 \mathrm{MHz}, \mathrm{CDCl}_{3}\right) \delta 5.65(\mathrm{ddt}, J=17.4,10.1,7.4 \mathrm{~Hz}$, $1 \mathrm{H}), 5.13(\mathrm{dd}, J=10.1,0.9 \mathrm{~Hz}, 1 \mathrm{H}), 5.04(\mathrm{dd}, J=16.9,1.5 \mathrm{~Hz}, 1 \mathrm{H})$, 3.84-3.81 (m, 1H), $3.80(\mathrm{~d}, J=10.6 \mathrm{~Hz}, 1 \mathrm{H}), 3.76(\mathrm{~s}, 1 \mathrm{H}), 3.66(\mathrm{~d}, J$ $=10.6 \mathrm{~Hz}, 1 \mathrm{H}), 2.70(\mathrm{dt}, J=12.8,3.4 \mathrm{~Hz}, 1 \mathrm{H}), 2.53-2.41(\mathrm{~m}, 3 \mathrm{H})$, $2.36(\mathrm{dd}, J=14.4,7.2 \mathrm{~Hz}, 1 \mathrm{H}), 2.26(\mathrm{dt}, J=15.0,5.5 \mathrm{~Hz}, 1 \mathrm{H}), 2.11$ $(\mathrm{dd}, J=14.5,7.6 \mathrm{~Hz}, 1 \mathrm{H}), 2.06(\mathrm{dq}, J=15.0,2.5 \mathrm{~Hz}, 1 \mathrm{H}), 1.56-1.52$ (m, $1 \mathrm{H}), 1.35-1.25(\mathrm{~m}, 1 \mathrm{H}), 1.15(\mathrm{dt}, J=13.6,3.7 \mathrm{~Hz}, 1 \mathrm{H}), 0.90(\mathrm{~s}$, $9 \mathrm{H}), 0.10(\mathrm{~s}, 6 \mathrm{H}) ;{ }^{13} \mathrm{C}$ NMR $\left(125 \mathrm{MHz}, \mathrm{CDCl}_{3}\right) \delta 210.3,155.2$, $131.3,119.4,80.4,67.8,61.1,49.2,40.8,40.6,33.8,30.3,26.8,25.8$, 21.3, 18.2, -5.4, -5.5; IR (film) 3077, 2952, 2931, 2857, 1760, 1712, $1640,1434,1257,1140,1093,840 \mathrm{~cm}^{-1}$; HRMS (ESI) calcd for $\left(\mathrm{C}_{20} \mathrm{H}_{33} \mathrm{NO}_{4} \mathrm{Si}\right) \mathrm{Na}^{+}(\mathrm{M}+\mathrm{Na})^{+}$402.2071, found 402.2061.

( + )-( $\left.{ }^{1} R, 6 \mathrm{a} R, 9 \mathrm{aS}\right)-6 \mathrm{a}-$ Allyl-9a-((tert-butyldimethylsilyl)oxy)methyl)-3 ${ }^{1}, 4,5,6,6 a, 9 a-h e x a h y d r o-2 H, 7 H$-oxazolo[5,4,3-ij]quinoline-2,7-dione (24). To a solution of ketone $22(3.809 \mathrm{~g}, 10.0$ mmol) in $40 \mathrm{~mL}$ of anhydrous THF and $3.5 \mathrm{~mL}$ of anhydrous DMPU was added LiHMDS (13.0 mL, $13.0 \mathrm{mmol}, 1.0 \mathrm{M}$ in THF) dropwise over $5 \mathrm{~min}$, at $-78{ }^{\circ} \mathrm{C}$, under nitrogen. The resulting dark brown-red solution was stirred at the same temperature for $30 \mathrm{~min}$ followed by the addition of a solution of $\mathrm{PhSeCl}(2.298 \mathrm{~g}, 12.0 \mathrm{mmol})$ in $10 \mathrm{~mL}$ of THF over $10 \mathrm{~min}$. The reaction mixture was stirred at $-78^{\circ} \mathrm{C}$ for $4 \mathrm{~h}$ and then warmed to room temperature. It was then quenched with $\mathrm{H}_{2} \mathrm{O}(40 \mathrm{~mL})$, and the aqueous phase was extracted once with EtOAc $(50 \mathrm{~mL})$. The organic phase was washed with $\mathrm{H}_{2} \mathrm{O}(25 \mathrm{~mL})$, dried over $\mathrm{MgSO}_{4}$, filtered, and concentrated in vacuo to afford a darkcolored oil. Purification by flash column chromatography (EtOAc/ hexanes $1: 3$ to $1: 2)$ gave the selenylated product $(4.438 \mathrm{~g})$ as a brown oil (dr 10:3 by ${ }^{1} \mathrm{H}$ NMR analysis). 
To a solution of the selenylated product $(4.438 \mathrm{~g})$ in $60 \mathrm{~mL}$ of $\mathrm{CH}_{2} \mathrm{Cl}_{2}$ were added sequentially anhydrous pyridine $(2.0 \mathrm{~mL}, 24.9$ $\mathrm{mmol})$ and $\mathrm{H}_{2} \mathrm{O}_{2}\left(2.8 \mathrm{~mL}, 24.9 \mathrm{mmol}, 30 \%\right.$ solution in $\mathrm{H}_{2} \mathrm{O}$ ) at room temperature, under air. Heat evolution was observed after a few minutes and the reaction mixture was cooled to $0{ }^{\circ} \mathrm{C}$. It was stirred at $0{ }^{\circ} \mathrm{C}$ for $10 \mathrm{~min}$ and then at room temperature for $30 \mathrm{~min}$, at which point it turned almost colorless. The reaction mixture was then quenched with $30 \mathrm{~mL}$ of a $1: 1$ mixture of saturated $\mathrm{Na}_{2} \mathrm{~S}_{2} \mathrm{O}_{3}$ and $\mathrm{NaHCO}_{3}$ solutions. The aqueous phase was extracted three times with EtOAc, and the combined organic phase was dried over $\mathrm{MgSO}_{4}$, filtered, and concentrated in vacuo to afford an orange oil. Purification by flash column chromatography (EtOAc/hexanes 1:3) gave pure enone 24 ( $1.564 \mathrm{~g}$, $41 \%$ over two steps) as a colorless oil: ${ }^{1} \mathrm{H}$ NMR $\left(500 \mathrm{MHz}, \mathrm{CDCl}_{3}\right) \delta 6.48(\mathrm{dd}, J=10.4,1.4 \mathrm{~Hz}, 1 \mathrm{H}), 6.13(\mathrm{~d}, J=10.4$ $\mathrm{Hz}, 1 \mathrm{H}), 5.64(\mathrm{ddt}, J=17.4,10.1,7.5 \mathrm{~Hz}, 1 \mathrm{H}), 5.15(\mathrm{dt}, J=10.1,0.7$ $\mathrm{Hz}, 1 \mathrm{H}), 5.05(\mathrm{dq}, J=6.9,1.4 \mathrm{~Hz}, 1 \mathrm{H}), 4.00(\mathrm{~d}, J=11.7 \mathrm{~Hz}, 1 \mathrm{H}), 3.89$ $(\mathrm{d}, J=1.3 \mathrm{~Hz}, 1 \mathrm{H}), 3.84(\mathrm{~d}, J=11.7 \mathrm{~Hz}, 1 \mathrm{H}), 3.78(\mathrm{dd}, J=12.7,5.1$ $\mathrm{Hz}, 1 \mathrm{H}), 2.69(\mathrm{dt}, J=12.8,3.5 \mathrm{~Hz}, 1 \mathrm{H}), 2.50-2.46(\mathrm{~m}, 1 \mathrm{H}), 2.32(\mathrm{dd}$, $J=14.0,7.2 \mathrm{~Hz}, 1 \mathrm{H}), 2.20(\mathrm{dd}, J=14.0,7.7 \mathrm{~Hz}, 1 \mathrm{H}), 1.65-1.60(\mathrm{~m}$, $1 \mathrm{H}), 1.39$ (ddq, $J=13.5,5.1,3.5 \mathrm{~Hz}, 1 \mathrm{H}), 1.14(\mathrm{dt}, J=13.7,3.8 \mathrm{~Hz}$, $1 \mathrm{H}), 0.91(\mathrm{~s}, 9 \mathrm{H}), 0.12(\mathrm{~s}, 3 \mathrm{H}), 0.11(\mathrm{~s}, 3 \mathrm{H}) ;{ }^{13} \mathrm{C}$ NMR $(125 \mathrm{MHz}$, $\left.\mathrm{CDCl}_{3}\right) \delta 198.7,154.5,139.3,130.8,130.0,120.0,79.2,65.4,60.8$, 47.5, 41.4, 41.1, 28.7, 25.8, 20.9, 18.3, -5.3, -5.4; IR (film) 2953, 2929, 2856, 1767, 1686, 1415, 1256, 1150,1091, $839 \mathrm{~cm}^{-1}$; HRMS (ESI) calcd for $\left(\mathrm{C}_{20} \mathrm{H}_{31} \mathrm{NO}_{4} \mathrm{Si}\right) \mathrm{Na}^{+}(\mathrm{M}+\mathrm{Na})^{+} 400.1915$, found 400.1907.

( \pm ) - ( $3^{1} R, 6$ a $R, 9$ aS $)-6$ a-Allyl-9a-(hydroxymethyl)$3^{1}, 4,5,6,6 a, 9 a-h e x a h y d r o-2 H, 7 H$-oxazolo[5,4,3-ij]quinoline-2,7dione (25). To a solution of the silyl ether $24(181 \mathrm{mg}, 0.48 \mathrm{mmol})$ in $5 \mathrm{~mL}$ of anhydrous THF was added TBAF $(0.72 \mathrm{~mL}, 0.72 \mathrm{mmol}, 1.0$ $\mathrm{M}$ in THF) at room temperature, under nitrogen. Upon addition of TBAF, the color of the solution turned orange immediately. After 45 min, the reaction mixture was quenched with $\mathrm{H}_{2} \mathrm{O}$, and the aqueous phase was extracted with EtOAc $(3 \times 10 \mathrm{~mL})$. The combined organic phase was dried over $\mathrm{MgSO}_{4}$, filtered, and concentrated in vacuo to afford an orange oil. Purification by flash column chromatography (EtOAc/hexanes, 2:1 to 3:1) gave pure alcohol $25(113 \mathrm{mg}, 90 \%)$ as a colorless oil.

This reaction was performed on a gram-scale using silyl ether $\mathbf{2 4}$ $(1.564 \mathrm{~g}, 4.1 \mathrm{mmol})$, TBAF $(6.2 \mathrm{~mL}, 6.2 \mathrm{mmol}, 1.0 \mathrm{M}$ in THF), and anhydrous THF $(30 \mathrm{~mL})$ using the same procedure. Alcohol 25 was obtained in $87 \%$ yield $(953 \mathrm{mg}):{ }^{1} \mathrm{H}$ NMR $\left(500 \mathrm{MHz}, \mathrm{CDCl}_{3}\right) \delta 6.49$ $(\mathrm{dd}, J=10.4,1.5 \mathrm{~Hz}, 1 \mathrm{H}), 6.14(\mathrm{~d}, J=10.4 \mathrm{~Hz}, 1 \mathrm{H}), 5.62(\mathrm{ddt}, J=$ $17.0,10.1,7.7 \mathrm{~Hz}, 1 \mathrm{H}), 5.16(\mathrm{dt}, J=10.0,0.7 \mathrm{~Hz}, 1 \mathrm{H}), 5.06(\mathrm{dq}, J=$ $16.9,1.4 \mathrm{~Hz}, 1 \mathrm{H}), 4.03(\mathrm{dd}, J=13.0,5.3 \mathrm{~Hz}, 1 \mathrm{H}), 4.01(\mathrm{~s}, 1 \mathrm{H}), 3.77-$ $3.71(\mathrm{~m}, 2 \mathrm{H}), 3.45(\mathrm{br} \mathrm{s}, 1 \mathrm{H}), 2.73(\mathrm{dt}, J=12.8,3.5 \mathrm{~Hz}, 1 \mathrm{H}), 2.50-$ $2.46(\mathrm{~m}, 1 \mathrm{H}), 2.28(\mathrm{dd}, J=14.0,7.0 \mathrm{~Hz}, 1 \mathrm{H}), 2.22(\mathrm{dd}, J=14.0,7.8$ $\mathrm{Hz}, 1 \mathrm{H}), 1.65-1.61(\mathrm{~m}, 1 \mathrm{H}), 1.39$ (ddq, $J=13.5,5.1,3.5 \mathrm{~Hz}, 1 \mathrm{H})$, $1.14(\mathrm{dt}, J=13.7,3.8 \mathrm{~Hz}, 1 \mathrm{H}) ;{ }^{13} \mathrm{C} \mathrm{NMR}\left(125 \mathrm{MHz}, \mathrm{CDCl}_{3}\right) \delta 198.5$, $154.9,138.6,130.5,130.3,120.2,79.8,64.1,59.9,47.5,41.2,41.1,28.6$, 20.8; IR (film) 3415 (br), 2935, 2866, 1759, 1684, 1436, 1387, 1293, $1145,1109,1027 \mathrm{~cm}^{-1}$; HRMS (ESI) calcd for $\left(\mathrm{C}_{14} \mathrm{H}_{17} \mathrm{NO}_{4}\right) \mathrm{Na}^{+}(\mathrm{M}$ $+\mathrm{Na})^{+} 286.1050$, found 286.1046 .

( \pm )-( $\left.{ }^{1} R, 6 \mathrm{a} R, 9 \mathrm{~S}, 9 \mathrm{aS}\right)-6 \mathrm{a}-A$ llyl-9-((2,3-dimethoxyphenyl)amino)-9a-(hydroxymethyl)octahydro- $2 \mathrm{H}, 7 \mathrm{H}$-oxazolo $[5,4,3-i j]$ quinoline-2,7-dione (27). A mixture of alcohol $25(20 \mathrm{mg}, 0.076$ $\mathrm{mmol})$, 2,3-dimethoxyaniline 26 (106 $\mathrm{mg}, 0.69 \mathrm{mmol})$, and $\mathrm{ZrOCl}_{2}$. $8 \mathrm{H}_{2} \mathrm{O}(12 \mathrm{mg}, 0.038 \mathrm{mmol})$ was stirred in an Eppendorf tube at 110 ${ }^{\circ} \mathrm{C}$ for $24 \mathrm{~h}$. The reaction mixture was then diluted with $\mathrm{CH}_{2} \mathrm{Cl}_{2}$, filtered, and concentrated in vacuo to give a black oil. Purification by flash column chromatography (EtOAc/hexanes $2: 1$ ) afforded the azaMichael addition product $27(4 \mathrm{mg}, 13 \%)$ along with unreacted alcohol 25 (12 mg, 60\%): ${ }^{1} \mathrm{H}$ NMR $\left(500 \mathrm{MHz}, \mathrm{CDCl}_{3}\right) \delta 6.91(\mathrm{t}, J=$ $8.2 \mathrm{~Hz}, 1 \mathrm{H}), 6.38(\mathrm{dd}, J=8.4,1.2 \mathrm{~Hz}, 1 \mathrm{H}), 6.24(\mathrm{~d}, J=8.3 \mathrm{~Hz}, 1 \mathrm{H})$, $5.74(\mathrm{ddt}, J=17.3,10.1,7.5 \mathrm{~Hz}, 1 \mathrm{H}), 5.22(\mathrm{dt}, J=10.1,0.7 \mathrm{~Hz}, 1 \mathrm{H})$, $5.15(\mathrm{dd}, J=16.9,1.5 \mathrm{~Hz}, 1 \mathrm{H}), 4.62(\mathrm{~d}, J=10.7 \mathrm{~Hz}, 1 \mathrm{H}), 4.28(\mathrm{ddd}, J$ $=13.3,10.7,4.2 \mathrm{~Hz}, 1 \mathrm{H}), 4.06(\mathrm{dd}, J=11.6,3.5 \mathrm{~Hz}, 1 \mathrm{H}), 3.98(\mathrm{~s}, 1 \mathrm{H})$, $3.88-3.79(\mathrm{~m}, 8 \mathrm{H}), 2.83(\mathrm{dd}, J=18.4,4.2 \mathrm{~Hz}, 1 \mathrm{H}), 2.78(\mathrm{dt}, J=12.7$, $3.7 \mathrm{~Hz}, 1 \mathrm{H}), 2.53-2.50(\mathrm{~m}, 1 \mathrm{H}), 2.43-2.36(\mathrm{~m}, 2 \mathrm{H}), 2.27(\mathrm{dd}, J=$ 14.5, 7.6 Hz, 1H), 2.15 (dd, $J=7.6,4.1 \mathrm{~Hz}, 1 \mathrm{H}), 1.37-1.27(\mathrm{~m}, 2 \mathrm{H})$;
${ }^{13} \mathrm{C}$ NMR $\left(125 \mathrm{MHz}, \mathrm{CDCl}_{3}\right) \delta 208.5,154.8,153.1,140.0,136.3$, 131.0, 124.5, 120.2, 104.7, 102.7, 82.4, 64.3, 61.1, 60.1, 55.8, 49.8, 48.8, 41.0, 40.9, 40.5, 30.3, 21.2; IR (film) 3397 (br), 2934, 1751, 1711, 1601, 1512, 1481, 1438, 1419, 1296, 1264, 1146, $1063 \mathrm{~cm}^{-1}$; HRMS (ESI) calcd for $\left(\mathrm{C}_{22} \mathrm{H}_{28} \mathrm{~N}_{2} \mathrm{O}_{6}\right) \mathrm{Na}^{+}(\mathrm{M}+\mathrm{Na})^{+}$439.1840, found 439.1832 .

( \pm$)-\left(\left(3^{1} R, 6 \mathrm{a} R, 9 \mathrm{a} S\right)-6 \mathrm{a}-A \mid l y l-2,7-d i o x o-5,6,6 \mathrm{a}, 7-t e t r a h y d r o-\right.$ $2 H, 4 H$-oxazolo[5,4,3-ij]quinolin-9a $\left(3^{1} H\right)$-yl)methyl $(2,3-$ Dimethoxyphenyl)carbamate (29). To a solution of 2,3dimethoxybenzoic acid $28(109 \mathrm{mg}, 0.6 \mathrm{mmol})$ in anhydrous THF $(1.0 \mathrm{~mL})$ were added, sequentially, DPPA $(129 \mu \mathrm{L}, 0.6 \mathrm{mmol}), \mathrm{Et}_{3} \mathrm{~N}$ $(113 \mu \mathrm{L}, 0.8 \mathrm{mmol})$, and a solution of alcohol $25(105 \mathrm{mg}, 0.4 \mathrm{mmol})$ in THF $(1.5 \mathrm{~mL})$ at room temperature, under nitrogen. The resulting clear, pale-yellow solution was heated to $70{ }^{\circ} \mathrm{C}$ and stirred at this temperature for $7 \mathrm{~h}$. It was then cooled to room temperature and quenched with saturated $\mathrm{NaHCO}_{3}$ solution $(5 \mathrm{~mL})$. The aqueous phase was extracted with EtOAc $(3 \times 15 \mathrm{~mL})$, and the combined organic phase was dried over $\mathrm{MgSO}_{4}$, filtered, and concentrated in vacuo to give a light yellow oil. Purification by flash column chromatography (EtOAc/hexanes, 1:2 to 1:1) afforded carbamate 29 $(166 \mathrm{mg}, 94 \%)$ as a colorless oil which solidified upon standing in the refrigerator: ${ }^{1} \mathrm{H}$ NMR $\left(500 \mathrm{MHz}, \mathrm{CDCl}_{3}, 295 \mathrm{~K}\right) \delta 7.70($ br s, $1 \mathrm{H})$, $7.50(\mathrm{br} \mathrm{s}, 1 \mathrm{H}), 7.04(\mathrm{t}, J=8.4 \mathrm{~Hz}, 1 \mathrm{H}), 6.67(\mathrm{dd}, J=8.4,1.3 \mathrm{~Hz}, 1 \mathrm{H})$, $6.59(\mathrm{dd}, J=10.4,1.6 \mathrm{~Hz}, 1 \mathrm{H}), 6.19(\mathrm{~d}, J=10.4 \mathrm{~Hz}, 1 \mathrm{H}), 5.62$ (dddd, $J=16.8,10.2,8.2,6.6 \mathrm{~Hz}, 1 \mathrm{H}), 5.16(\mathrm{~d}, J=9.9 \mathrm{~Hz}, 1 \mathrm{H}), 5.09(\mathrm{dd}, J=$ $16.9,1.3 \mathrm{~Hz}, 1 \mathrm{H}), 4.60(\mathrm{~d}, J=12.4 \mathrm{~Hz}, 1 \mathrm{H}), 4.48(\mathrm{~d}, J=12.4 \mathrm{~Hz}, 1 \mathrm{H})$, $3.90(\mathrm{~s}, 3 \mathrm{H}), 3.88(\mathrm{~s}, 3 \mathrm{H}), 3.83(\mathrm{~d}, J=1.5 \mathrm{~Hz}, 1 \mathrm{H}), 3.83-3.79(\mathrm{~m}$, $1 \mathrm{H}), 2.77(\mathrm{dt}, J=12.8,3.5 \mathrm{~Hz}, 1 \mathrm{H}), 2.54-2.50(\mathrm{~m}, 1 \mathrm{H}), 2.38(\mathrm{dd}, J=$ $14.1,6.5 \mathrm{~Hz}, 1 \mathrm{H}), 2.26(\mathrm{dd}, J=14.1,8.2 \mathrm{~Hz}, 1 \mathrm{H}), 1.68-1.64(\mathrm{~m}, 1 \mathrm{H})$, $1.46-1.37(\mathrm{~m}, 1 \mathrm{H}), 1.17(\mathrm{dt}, J=13.7,3.7 \mathrm{~Hz}, 1 \mathrm{H}) ;{ }^{1} \mathrm{H}$ NMR $(500$ $\left.\mathrm{MHz}, \mathrm{CDCl}_{3}, 323 \mathrm{~K}\right) \delta 7.66(\mathrm{~d}, J=8.3 \mathrm{~Hz}, 1 \mathrm{H}), 7.41(\mathrm{br} \mathrm{s}, 1 \mathrm{H}), 7.01$ $(\mathrm{t}, J=8.4 \mathrm{~Hz}, 1 \mathrm{H}), 6.66(\mathrm{~d}, J=8.3 \mathrm{~Hz}, 1 \mathrm{H}), 6.56(\mathrm{dd}, J=10.4,1.5 \mathrm{~Hz}$, $1 \mathrm{H}), 6.16(\mathrm{~d}, J=10.4 \mathrm{~Hz}, 1 \mathrm{H}), 5.62$ (dddd, $J=16.9,10.2,8.0,6.7 \mathrm{~Hz}$, $1 \mathrm{H}), 5.15(\mathrm{~d}, J=10.2 \mathrm{~Hz}, 1 \mathrm{H}), 5.08(\mathrm{dd}, J=16.9,1.4 \mathrm{~Hz}, 1 \mathrm{H}), 4.59$ $(\mathrm{d}, J=12.3 \mathrm{~Hz}, 1 \mathrm{H}), 4.48(\mathrm{~d}, J=12.4 \mathrm{~Hz}, 1 \mathrm{H}), 3.89(\mathrm{~s}, 3 \mathrm{H}), 3.86(\mathrm{~s}$, $3 \mathrm{H}), 3.82-3.79(\mathrm{~m}, 2 \mathrm{H}), 2.74(\mathrm{dt}, J=12.8,3.4 \mathrm{~Hz}, 1 \mathrm{H}), 2.55-2.49$ (m, $1 \mathrm{H}), 2.37(\mathrm{dd}, J=14.2,6.6 \mathrm{~Hz}, 1 \mathrm{H}), 2.25(\mathrm{dd}, J=14.2,8.0 \mathrm{~Hz}$, $1 \mathrm{H}), 1.66-1.62(\mathrm{~m}, 1 \mathrm{H}), 1.47-1.37(\mathrm{~m}, 1 \mathrm{H}), 1.15(\mathrm{dt}, J=13.7,3.7$ $\mathrm{Hz}, 1 \mathrm{H}) ;{ }^{13} \mathrm{C}$ NMR $\left(125 \mathrm{MHz}, \mathrm{CDCl}_{3}, 323 \mathrm{~K}\right) \delta 197.6,154.1,152.3$, $152.2,137.8,137.7,131.4,130.5,130.3,124.1,120.1,111.4,107.9$, 77.2, 65.8, 61.7, 60.8, 56.0, 47.6, 41.3, 41.2, 28.9, 20.8; IR (film) 3321, 2941, 1766, 1686, 1606, 1535, 1481, 1462, 1422, 1233, 1205, 1057, $1028,920 \mathrm{~cm}^{-1}$; HRMS (ESI) calcd for $\left(\mathrm{C}_{23} \mathrm{H}_{26} \mathrm{~N}_{2} \mathrm{O}_{7} \mathrm{Na}\right)^{+}(\mathrm{M}+\mathrm{Na})^{+}$ 465.1632 , found 465.1652 .

( \pm )-(4aS, $\left.4 \mathrm{a}^{1} R, 10 \mathrm{a} R, 12 \mathrm{a} R\right)$-10a-Allyl-1-(2,3-dimethoxyphenyl)hexahydro- $2 H, 4 H, 6 H, 8 H-[1,3]$ oxazino[4,5-h]oxazolo[5,4,3-ij]quinoline-2,6,11(1H)-trione (30). To a solution of carbamate $29(109 \mathrm{mg}, 0.25 \mathrm{mmol})$ in $1.5 \mathrm{~mL}$ of anhydrous $\mathrm{CHCl}_{3}$ were added sequentially $i$ - $\mathrm{Pr}_{2} \mathrm{NEt}(174 \mu \mathrm{L}, 1.0 \mathrm{mmol})$ and TBSOTf $(574 \mu \mathrm{L}, 2.5 \mathrm{mmol})$ at room temperature under nitrogen. The reaction mixture was heated to $60^{\circ} \mathrm{C}$ and stirred at this temperature for $18 \mathrm{~h}$. It was then cooled to room temperature and quenched with a saturated $\mathrm{NaHCO}_{3}$ solution. The aqueous phase was extracted three times with $\mathrm{CH}_{2} \mathrm{Cl}_{2}$, and the combined organic phase was dried over $\mathrm{MgSO}_{4}$, filtered, and concentrated in vacuo. Purification by flash column chromatography $\left(4 \% \mathrm{MeOH}\right.$ in $\mathrm{CHCl}_{3}$ ) afforded cyclized carbamate product $30(87 \mathrm{mg}, 80 \%)$ as a white solid: $\mathrm{mp} 239-240{ }^{\circ} \mathrm{C} \mathrm{dec} ;{ }^{1} \mathrm{H}$ $\operatorname{NMR}\left(500 \mathrm{MHz}, \mathrm{CDCl}_{3}, 295 \mathrm{~K}\right) \delta 7.09(\mathrm{t}, J=8.2 \mathrm{~Hz}, 1 \mathrm{H}), 6.95(\mathrm{dd}, J$ $=8.4,1.3 \mathrm{~Hz}, 1 \mathrm{H}), 6.75(\mathrm{br} \mathrm{d}, J=7.8 \mathrm{~Hz}, 1 \mathrm{H}), 5.60$ (ddt, $J=17.0$, $10.1,7.6 \mathrm{~Hz}, 1 \mathrm{H}), 5.22(\mathrm{~d}, J=9.9 \mathrm{~Hz}, 1 \mathrm{H}), 5.18(\mathrm{dd}, J=16.9,1.2 \mathrm{~Hz}$, $1 \mathrm{H}), 4.86(\mathrm{~d}, J=12.1 \mathrm{~Hz}, 1 \mathrm{H}), 4.65(\mathrm{dd}, J=12.1,1.4 \mathrm{~Hz}, 1 \mathrm{H}), 4.31$ (br s, $1 \mathrm{H}), 3.90(\mathrm{~s}, 3 \mathrm{H}), 3.88(\mathrm{~s}, 3 \mathrm{H}), 3.79(\mathrm{dd}, J=12.8,4.5 \mathrm{~Hz}, 1 \mathrm{H})$, $3.75(\mathrm{~s}, 1 \mathrm{H}), 2.76-2.68(\mathrm{~m}, 2 \mathrm{H}), 2.55(\mathrm{dd}, J=15.5,5.0 \mathrm{~Hz}, 1 \mathrm{H})$, $2.50-2.46(\mathrm{~m}, 2 \mathrm{H}), 2.30(\mathrm{dd}, J=14.2,7.9 \mathrm{~Hz}, 1 \mathrm{H}), 1.67-1.64(\mathrm{~m}$, $1 \mathrm{H}), 1.42-1.30(\mathrm{~m}, 1 \mathrm{H}), 1.17(\mathrm{dt}, J=8.0,3.2 \mathrm{~Hz}, 1 \mathrm{H}) ;{ }^{1} \mathrm{H}$ NMR $(500$ MHz, DMSO- $\left.d_{6}, 353 \mathrm{~K}\right) \delta 7.09-7.07(\mathrm{~m}, 2 \mathrm{H}), 6.76(\mathrm{dd}, J=6.1,3.4$ $\mathrm{Hz}, 1 \mathrm{H}), 5.57(\mathrm{ddt}, J=17.2,10.1,7.3 \mathrm{~Hz}, 1 \mathrm{H}), 5.32(\mathrm{~d}, J=12.3 \mathrm{~Hz}$, $1 \mathrm{H}), 5.19(\mathrm{dd}, J=17.0,1.8 \mathrm{~Hz}, 1 \mathrm{H}), 5.11(\mathrm{dd}, J=10.1,1.9 \mathrm{~Hz}, 1 \mathrm{H})$, $4.62(\mathrm{dd}, J=12.3,2.0 \mathrm{~Hz}, 1 \mathrm{H}), 4.05$ (ddd, $J=12.4,5.1,1.8 \mathrm{~Hz}, 1 \mathrm{H})$, $3.95(\mathrm{~s}, 1 \mathrm{H}), 3.85(\mathrm{~s}, 3 \mathrm{H}), 3.75(\mathrm{~s}, 3 \mathrm{H}), 3.57-3.54(\mathrm{~m}, 1 \mathrm{H}), 3.21(\mathrm{t}, J$ 
$=13.5 \mathrm{~Hz}, 1 \mathrm{H}), 2.70(\mathrm{dt}, J=12.3,3.2 \mathrm{~Hz}, 1 \mathrm{H}), 2.56(\mathrm{dd}, J=14.2,7.2$ $\mathrm{Hz}, 1 \mathrm{H}), 2.34-2.26(\mathrm{~m}, 3 \mathrm{H}), 1.59-1.55(\mathrm{~m}, 1 \mathrm{H}), 1.30-1.20(\mathrm{~m}, 1 \mathrm{H})$, $1.13(\mathrm{dt}, J=13.5,3.4 \mathrm{~Hz}, 1 \mathrm{H}) ;{ }^{13} \mathrm{C}$ NMR $\left(125 \mathrm{MHz}\right.$, DMSO- $d_{6}, 353$ K) $\delta 205.4,153.6,153.1,150.1,145.2,132.8,130.7,123.0,121.4$, 119.1, 113.1, 74.9, 66.6, 62.1, 60.4, 59.7, 55.8, 48.5, 40.7, 40.3, 39.8, 27.4, 19.8; IR (film) 2941, 2840, 2252, 1771, 1710, 1590, 1489, 1477, 1436, 1267, 1231, 1183, 1002, 922, $851 \mathrm{~cm}^{-1}$; HRMS (ESI) calcd for $\left(\mathrm{C}_{23} \mathrm{H}_{27} \mathrm{~N}_{2} \mathrm{O}_{7}\right)^{+}(\mathrm{M}+\mathrm{H})^{+} 443.1813$, found 443.1820 .

Compounds 33 and 34. To a solution of $30(17.6 \mathrm{mg}, 0.04$ mmol) in $1.5 \mathrm{~mL}$ of anhydrous $\mathrm{CH}_{2} \mathrm{Cl}_{2}$ was added $\mathrm{Me}_{3} \mathrm{OBF}_{4}(24 \mathrm{mg}$, $0.16 \mathrm{mmol}$ ), and the resulting mixture was stirred at $32-34{ }^{\circ} \mathrm{C}$ under nitrogen for $3 \mathrm{~h}$. It was then cooled to room temperature and quenched with $\mathrm{H}_{2} \mathrm{O}$. The aqueous phase was extracted three times with $\mathrm{CH}_{2} \mathrm{Cl}_{2}$, and the combined organic phase was dried over $\mathrm{MgSO}_{4}$, filtered, and concentrated in vacuo. Purification by PTLC (EtOAc/ hexanes, $2: 1)$ afforded $33(7.1 \mathrm{mg}, 38 \%)$ and $34(6.6 \mathrm{mg}, 35 \%)$.

( \pm$)-\left(\left(3^{1} R, 6 \mathrm{a} R, 9 R, 9 \mathrm{aS}\right)-6 \mathrm{a}-A l l y l-9-((2,3-\right.$ dimethoxyphenyl)amino)-2,7-dioxohexahydro- $2 \mathrm{H}, 4 \mathrm{H}$-oxazolo[5,4,3-ij]quinolin9a $\left(3^{1} H\right)$-yl)methyl methyl carbonate (33): ${ }^{1} \mathrm{H}$ NMR $(500 \mathrm{MHz}$, $\left.\mathrm{CDCl}_{3}\right) \delta 6.96(\mathrm{t}, J=8.3 \mathrm{~Hz}, 1 \mathrm{H}), 6.47(\mathrm{~d}, J=8.1 \mathrm{~Hz}, 1 \mathrm{H}), 6.41(\mathrm{dd}, J$ $=8.3,1.0 \mathrm{~Hz}, 1 \mathrm{H}), 5.71(\mathrm{ddt}, J=17.3,10.1,7.3 \mathrm{~Hz}, 1 \mathrm{H}), 5.19(\mathrm{~d}, J=$ $10.2 \mathrm{~Hz}, 1 \mathrm{H}), 5.16(\mathrm{dd}, J=16.9,1.4 \mathrm{~Hz}, 1 \mathrm{H}), 4.78(\mathrm{~d}, J=12.4 \mathrm{~Hz}$, $1 \mathrm{H}), 4.52(\mathrm{~d}, J=12.5 \mathrm{~Hz}, 1 \mathrm{H}), 4.19(\mathrm{~d}, J=8.4 \mathrm{~Hz}, 1 \mathrm{H}), 4.10-4.06$ $(\mathrm{m}, 1 \mathrm{H}), 3.92(\mathrm{~s}, 1 \mathrm{H}), 3.87-3.83(\mathrm{~m}, 4 \mathrm{H}), 3.80(\mathrm{~s}, 3 \mathrm{H}), 3.76(\mathrm{~s}, 3 \mathrm{H})$, $2.79-2.73(\mathrm{~m}, 3 \mathrm{H}), 2.60(\mathrm{dd}, J=14.4,7.1 \mathrm{~Hz}, 1 \mathrm{H}), 2.55($ app d, $J=$ $13.6 \mathrm{~Hz}, 1 \mathrm{H}), 2.32$ (dd, $J=14.4,7.6 \mathrm{~Hz}, 1 \mathrm{H}), 1.68-1.64(\mathrm{~m}, 1 \mathrm{H})$, $1.37-1.21(\mathrm{~m}, 2 \mathrm{H}) ;{ }^{13} \mathrm{C} \mathrm{NMR}\left(125 \mathrm{MHz}, \mathrm{CDCl}_{3}\right) \delta 208.0,155.0$, 154.7, 152.4, 140.1, 135.9, 130.5, 124.6, 120.2, 105.3, 103.3, 82.1, 67.5, 61.1, 60.2, 56.1, 55.7, 55.3, 48.6, 42.7, 41.6, 41.2, 30.8, 21.1; IR (film) 2917, 2849, 1756, 1716, 1602, 1481, 1457, 1442, $1264 \mathrm{~cm}^{-1}$; HRMS (ESI) calcd for $\left(\mathrm{C}_{24} \mathrm{H}_{30} \mathrm{~N}_{2} \mathrm{O}_{8}\right) \mathrm{Na}^{+}(\mathrm{M}+\mathrm{Na})^{+}$497.1894, found 497.1887.

( \pm )-Methyl (( $\left.3^{1} R, 6 \mathrm{a} R, 9 R, 9 \mathrm{a} S\right)-6 \mathrm{a}-\mathrm{allyl}-9 \mathrm{a}$-(hydroxymethyl)2,7-dioxooctahydro- $2 H, 4 H$-oxazolo $[5,4,3-i j]$ quinolin-9-yl)(2,3dimethoxyphenyl)carbamate (34): ${ }^{25}{ }^{1} \mathrm{H} \mathrm{NMR}\left(500 \mathrm{MHz}, \mathrm{CDCl}_{3}\right.$, $295 \mathrm{~K}) \delta 7.06$ (major rotamer, $\mathrm{t}, J=8.2 \mathrm{~Hz}, 1 \mathrm{H}$ ), 6.99 (minor rotamer, $\mathrm{t}, J=8.2 \mathrm{~Hz}, 1 \mathrm{H}$ ), 6.83 (major rotamer, dd, $J=8.1,1.6 \mathrm{~Hz}, 1 \mathrm{H}$ ), 6.88 (major rotamer, dd, $J=8.4,1.5 \mathrm{~Hz}, 1 \mathrm{H}$ ), 6.85 (minor rotamer, dd, $J=$ 8.4, $1.4 \mathrm{~Hz}, 1 \mathrm{H}), 6.64$ (minor rotamer, br d, $J=7.6 \mathrm{~Hz}, 1 \mathrm{H}), 5.63-$ $5.55(\mathrm{~m}, 1 \mathrm{H}), 5.17-5.12(\mathrm{~m}, 2 \mathrm{H}), 4.55$ (minor rotamer, br s, $1 \mathrm{H})$, 4.43-4.39 (major rotamer, $\mathrm{m}, 1 \mathrm{H}), 4.13-3.98(\mathrm{~m}, 4 \mathrm{H}), 3.91-3.82$ $(\mathrm{m}, 6 \mathrm{H}), 3.73-3.66(\mathrm{~m}, 4 \mathrm{H}), 3.61-3.55(\mathrm{~m}, 1 \mathrm{H}), 2.98(\mathrm{dd}, J=14.1$, $7.3 \mathrm{~Hz}, 1 \mathrm{H}), 2.82(\mathrm{dd}, J=14.1,4.1 \mathrm{~Hz}, 1 \mathrm{H}), 2.61-2.48(\mathrm{~m}, 2 \mathrm{H}), 2.36$ (dd, $J=14.1,7.4 \mathrm{~Hz}, 1 \mathrm{H}), 1.62-1.56(\mathrm{~m}, 1 \mathrm{H}), 1.48-1.31(\mathrm{~m}, 1 \mathrm{H})$, 1.07-0.98 (m, 1H); IR (film) 3415 (br), 2951, 2849, 1763, 1713, 1590, 1478, 1451, 1310,1077, $1011 \mathrm{~cm}^{-1}$; HRMS (ESI) Calcd for $\left(\mathrm{C}_{24} \mathrm{H}_{30} \mathrm{~N}_{2} \mathrm{O}_{8}\right) \mathrm{Na}^{+}(\mathrm{M}+\mathrm{Na})^{+}$497.1894, found 497.1890.

$( \pm)-\left(3^{1} R, 6 \mathrm{a} R, 9 R, 9 \mathrm{a} S\right)-6 \mathrm{a}-\mathrm{Allyl}-9-((2,3-$ dimethoxyphenyl)amino)-9a-(hydroxymethyl)octahydro- $2 \mathrm{H}, 7 \mathrm{H}$-oxazolo[5,4,3-ij]quinoline-2,7-dione (32). To a solution of the carbonate 33 (11.9 $\mathrm{mg}, 0.025 \mathrm{mmol})$ in $2.0 \mathrm{~mL}$ of $\mathrm{MeOH}$ was added $\mathrm{K}_{2} \mathrm{CO}_{3}(10.4 \mathrm{mg}$, $0.075 \mathrm{mmol}$ ). The resulting mixture was stirred for $30 \mathrm{~min}$, at which time TLC analysis showed full consumption of the starting material. It was then quenched with saturated $\mathrm{NH}_{4} \mathrm{Cl}$ solution $(3 \mathrm{~mL})$ and diluted with $\mathrm{H}_{2} \mathrm{O}(5 \mathrm{~mL})$, and the aqueous phase was extracted with EtOAc $(3 \times 10 \mathrm{~mL})$. The combined organic phase was dried over $\mathrm{MgSO}_{4}$, filtered, and concentrated in vacuo. Purification by flash column chromatography (EtOAc:hexanes, 1:1 to 2:1) gave pure $32(10.0 \mathrm{mg}$, $96 \%)$ as a colorless oil: ${ }^{1} \mathrm{H} \mathrm{NMR}\left(500 \mathrm{MHz}, \mathrm{CDCl}_{3}\right) \delta 6.95(\mathrm{t}, J=8.3$ $\mathrm{Hz}, 1 \mathrm{H}), 6.42(\mathrm{~d}, J=8.5 \mathrm{~Hz}, 1 \mathrm{H}), 6.40(\mathrm{~d}, J=8.4 \mathrm{~Hz}, 1 \mathrm{H}), 5.74(\mathrm{ddt}$, $J=17.3,10.1,7.4 \mathrm{~Hz}, 1 \mathrm{H}), 5.19(\mathrm{~d}, J=10.8 \mathrm{~Hz}, 1 \mathrm{H}), 5.17(\mathrm{~d}, J=17.4$ $\mathrm{Hz}, 1 \mathrm{H}), 4.31$ (br d, $J=6.5 \mathrm{~Hz}, 1 \mathrm{H}), 4.20(\mathrm{~d}, J=12.8 \mathrm{~Hz}, 1 \mathrm{H}), 4.07-$ $4.02(\mathrm{~m}, 1 \mathrm{H}), 4.04(\mathrm{~s}, 1 \mathrm{H}), 3.85-3.80(\mathrm{~m}, 1 \mathrm{H}), 3.84(\mathrm{~s}, 3 \mathrm{H}), 3.75(\mathrm{~s}$, $3 \mathrm{H}), 2.79-2.70(\mathrm{~m}, 3 \mathrm{H}), 2.66-2.57(\mathrm{~m}, 2 \mathrm{H}), 2.53$ (app d, $J=13.6$ $\mathrm{Hz}, 1 \mathrm{H}), 2.36(\mathrm{dd}, J=14.4,7.5 \mathrm{~Hz}, 1 \mathrm{H}), 1.66-1.63(\mathrm{~m}, 1 \mathrm{H}), 1.38-$ $1.16(\mathrm{~m}, 2 \mathrm{H}) ;{ }^{13} \mathrm{C} \mathrm{NMR}\left(125 \mathrm{MHz}, \mathrm{CDCl}_{3}\right) \delta 208.7,155.2,152.5$, $140.3,135.9,130.9,124.6,120.1,105.2,103.1,84.1,63.7,60.6,60.2$, 55.9, 55.8, 48.6, 42.9, 41.5, 41.2, 30.8, 21.2; IR (film) 3377 (br), 2932, $2854,1747,1715,1602,1516,1481,1306,1263,1219,1138 \mathrm{~cm}^{-1}$;
HRMS (ESI) calcd for $\left(\mathrm{C}_{22} \mathrm{H}_{28} \mathrm{~N}_{2} \mathrm{O}_{6}\right) \mathrm{Na}^{+}(\mathrm{M}+\mathrm{Na})^{+} 439.1840$, found 439.1837.

( \pm )-36. To a solution of alcohol $32(5.6 \mathrm{mg}, 0.013 \mathrm{mmol})$ in 0.6 $\mathrm{mL}$ of anhydrous $\mathrm{CH}_{2} \mathrm{Cl}_{2}$ was added DMP $(8.6 \mathrm{mg}, 0.02 \mathrm{mmol})$ and a few crystals of $\mathrm{KHCO}_{3}$. The resulting mixture was stirred at room temperature, under nitrogen for $5 \mathrm{~h}$, and then quenched with a 1:1 mixture of saturated $\mathrm{Na}_{2} \mathrm{~S}_{2} \mathrm{O}_{3}$ and $\mathrm{NaHCO}_{3}$ solutions. The aqueous phase was extracted three times with $\mathrm{CH}_{2} \mathrm{Cl}_{2}$, and the combined organic phase was dried over $\mathrm{MgSO}_{4}$, filtered, and concentrated in vacuo. Purification by PTLC (EtOAc/hexanes, 2:1) afforded 36 (2.7 $\mathrm{mg}, 49 \%)$ as a bright yellow oil: ${ }^{1} \mathrm{H}$ NMR $\left(500 \mathrm{MHz}, \mathrm{CDCl}_{3}\right)^{26} \delta 7.72$ $(\mathrm{d}, J=9.1 \mathrm{~Hz}, 1 \mathrm{H}), 6.54(\mathrm{~d}, J=9.1 \mathrm{~Hz}, 1 \mathrm{H}), 5.55$ (dddd, $J=16.8$, $10.0,8.3,6.7 \mathrm{~Hz}, 1 \mathrm{H}), 4.99(\mathrm{~d}, J=10.1 \mathrm{~Hz}, 1 \mathrm{H}), 4.88(\mathrm{~s}, 1 \mathrm{H}), 4.65$ $(\mathrm{dd}, J=16.9,1.4 \mathrm{~Hz}, 1 \mathrm{H}), 4.26(\mathrm{dt}, J=3.8,1.5 \mathrm{~Hz}, 1 \mathrm{H}), 4.06(\mathrm{~s}, 1 \mathrm{H})$, $3.94(\mathrm{~s}, 3 \mathrm{H}), 3.89-3.86(\mathrm{~m}, 1 \mathrm{H}), 3.80(\mathrm{~s}, 3 \mathrm{H}), 2.88-2.75(\mathrm{~m}, 3 \mathrm{H})$, $2.48-2.45(\mathrm{~m}, 1 \mathrm{H}), 2.37(\mathrm{dd}, J=14.2,6.7 \mathrm{~Hz}, 1 \mathrm{H}), 2.29(\mathrm{dd}, J=14.2$, $8.3 \mathrm{~Hz}, 1 \mathrm{H}), 1.63-1.60(\mathrm{~m}, 1 \mathrm{H}), 1.32-1.21(\mathrm{~m}, 2 \mathrm{H}) ;{ }^{13} \mathrm{C}$ NMR $(125$ $\left.\mathrm{MHz}, \mathrm{CDCl}_{3}\right) \delta 208.9,186.7,158.1,154.6,144.0,134.0,131.2$, 125.5, $120.1,112.0,104.9,77.7,62.3,60.5,56.1,55.2,48.6,41.8,41.2,41.0$, 31.1, 21.3; IR (film) 3328 (br), 2934, 2850, 1764, 1712, 1667, 1608, $1525,1479,1346,1272,1211,1037 \mathrm{~cm}^{-1}$; HRMS (ESI) calcd for $\left(\mathrm{C}_{22} \mathrm{H}_{24} \mathrm{~N}_{2} \mathrm{O}_{6}\right) \mathrm{K}^{+}(\mathrm{M}+\mathrm{K})^{+}$451.1266, found 451.1262.

\section{ASSOCIATED CONTENT}

Supporting Information

The Supporting Information is available free of charge on the ACS Publications website at DOI: 10.1021/acs.joc.6b01574.

X-ray crystallographic data for $\mathbf{3 0}$ (CIF)

HPLC chromatograms for 15 and ${ }^{1} \mathrm{H}$ and ${ }^{13} \mathrm{C}$ NMR spectra (PDF)

\section{AUTHOR INFORMATION}

\section{Corresponding Author}

*E-mail: vrawal@uchicago.edu.

\section{Present Addresses}

${ }^{\dagger}$ Department of Chemistry and UNAM-Institute of Materials Science and Nanotechnology, Bilkent University, 06800 Ankara, Turkey.

${ }^{\ddagger}$ Department of Chemistry, University of Saskatchewan, 110 Science Place, Saskatoon, Saskatchewan S7N 5C9, Canada.

\section{Notes}

The authors declare no competing financial interest.

${ }^{\S}$ ISHC member.

\section{ACKNOWLEDGMENTS}

We thank the University of Chicago for partial support of this work and the Natural Sciences and Engineering Research Council of Canada for a postdoctoral fellowship to M.G. We thank Prof. Chong Zheng (Northern Illinois University) for securing the crystal structure of 30 .

\section{REFERENCES}

(1) (a) Rogers, E. F.; Snyder, H. R.; Fischer, R. F. J. Am. Chem. Soc. 1952, 74, 1987-1989. (b) Snyder, H. R.; Fischer, R. F.; Walker, J. F.; Els, H. E.; Nussberger, G. A. J. Am. Chem. Soc. 1954, 76, 2819-2825. (c) Snyder, H. R.; Fischer, R. F.; Walker, J. F.; Els, H. E.; Nussberger, G. A. J. Am. Chem. Soc. 1954, 76, 4601-4605. (d) Snyder, H. R; Strohmayer, H. F.; Mooney, R. A. J. Am. Chem. Soc. 1958, 80, 37083710.

(2) Crosby, D. G. In Naturally Occurring Insecticides; Jacobson, M., Crosby, D. G., Eds.; Marcel Dekker: New York, 1971; pp 213-215.

(3) (a) Rae, I. D.; Rosenberger, M.; Szabo, A. G.; Willis, C. R.; Yates, P.; Zacharias, D. E.; Jeffrey, G. A.; Douglas, B.; Kirkpatrick, J. L.; Weisbach, J. A. J. Am. Chem. Soc. 1967, 89, 3061-3062. (b) Zacharias, D. E. Acta Crystallogr., Sect. B: Struct. Crystallogr. Cryst. Chem. 1970, 26, 
1455-1464. (c) Yates, P.; MacLachlan, F. N.; Rae, I. D.; Rosenberger, M.; Szabo, A. G.; Willis, C. R.; Cava, M. P.; Behforouz, M.; Lakshmikantham, M. V.; Zeiger, W. J. Am. Chem. Soc. 1973, 95, 78427850 .

(4) Mroue, M. A.; Euler, K. L.; Ghuman, M. A.; Alam, M. J. Nat. Prod. 1996, 59, 890-893.

(5) Synthetic studies toward haplophytine: (a) Yates, P.; Schwartz, D. A. Can. J. Chem. 1983, 61, 509-518. (b) Schwartz, D. A.; Yates, P. Can. J. Chem. 1983, 61, 1126-1131. (c) Rege, P. D.; Tian, Y.; Corey, E. J. Org. Lett. 2006, 8, 3117-3120. (d) Matsumoto, K.; Tokuyama, H.; Fukuyama, T. Synlett 2007, 2007, 3137-3140. (e) Nicolaou, K. C.; Majumder, U.; Roche, S. P.; Chen, D. Y.-K. Angew. Chem., Int. Ed. 2007, 46, 4715-4718. (f) Chughtai, M.; Eagan, J. M.; Padwa, A. Synlett 2011, 2011, 215-218.

(6) Completed syntheses of haplophytine: (a) Ueda, H.; Satoh, H.; Matsumoto, K.; Sugimoto, K.; Fukuyama, T.; Tokuyama, H. Angew. Chem., Int. Ed. 2009, 48, 7600-7603. (b) Nicolaou, K. C.; Dalby, S. M.; Li, S.; Suzuki, T.; Chen, D. Y.-K. Angew. Chem., Int. Ed. 2009, 48, 7616-7620. (c) Tian, W.; Chennamaneni, L. R.; Suzuki, T.; Chen, D. Y.-K. Eur. J. Org. Chem. 2011, 2011, 1027-1031.

(7) (a) He, F.; Bo, Y.; Altom, J. D.; Corey, E. J. J. Am. Chem. Soc. 1999, 121, 6771-6772. (b) Sumi, S.; Matsumoto, K.; Tokuyama, H.; Fukuyama, T. Org. Lett. 2003, 5, 1891-1893. (c) Sumi, S.; Matsumoto, K.; Tokuyama, H.; Fukuyama, T. Tetrahedron 2003, 59, 8571-8587. (d) Mejía-Oneto, J. M.; Padwa, A. Org. Lett. 2006, 8, 3275-3278. (e) Mejía-Oneto, J. M.; Padwa, A. Helv. Chim. Acta 2008, 91, 285-302. (f) Marino, J. P.; Cao, G. Tetrahedron Lett. 2006, 47, 7711-7713. (g) Nicolaou, K. C.; Dalby, S. M.; Majumder, U. J. Am. Chem. Soc. 2008, 130, 14942-14943. (h) Satoh, H.; Ueda, H.; Tokuyama, H. Tetrahedron 2013, 69, 89-95. (i) Yang, R; Qiu, F. G. Angew. Chem., Int. Ed. 2013, 52, 6015-6018.

(8) (a) Kozmin, S. A.; Rawal, V. H. J. Org. Chem. 1997, 62, 52525253. (b) Kozmin, S. A.; Rawal, V. H. J. Am. Chem. Soc. 1999, 121, 9562-9573. (c) Huang, Y.; Iwama, T.; Rawal, V. H. J. Am. Chem. Soc. 2000, 122, 7843-7844. (d) Huang, Y.; Iwama, T.; Rawal, V. H. J. Am. Chem. Soc. 2002, 124, 5950-5951. (e) Huang, Y.; Rawal, V. H. J. Am. Chem. Soc. 2002, 124, 9662-9663. (f) Huang, Y.; Unni, A. K.; Thadani, A. N.; Rawal, V. H. Nature 2003, 424, 146. (g) McGilvra, J. D.; Rawal, V. H. Synlett 2004, 2440-2442. (h) Watanabe, Y.; Washio, T.; Shimada, N.; Anada, M.; Hashimoto, S. Chem. Commun. 2009, 7294-7296.

(9) For recent reports on other electron-rich dienes, see: (a) Sammis, G. M.; Flamme, E. M.; Xie, H.; Ho, D. M.; Sorensen, E. J. J. Am. Chem. Soc. 2005, 127, 8612-8613. (b) Holmes, J. M.; Albert, A. L.; Gravel, M. J. Org. Chem. 2009, 74, 6406-6409. (c) Zhou, S.; Sánchez-Larios, E.; Gravel, M. J. Org. Chem. 2012, 77, 3576-3582. (d) Choi, J.; Park, H.; Yoo, H. J.; Kim, S.; Sorensen, E. J.; Lee, C. J. Am. Chem. Soc. 2014, 136, 9918-9921. (e) Weaver, M. G.; Bai, W.-J.; Jackson, S. K.; Pettus, T. R. R. Org. Lett. 2014, 16, 1294-1297.

(10) (a) Kozmin, S. A.; Rawal, V. H. J. Am. Chem. Soc. 1997, 119, 7165-7166. (b) Kozmin, S. A.; Rawal, V. H. J. Am. Chem. Soc. 1998, 120, 13523-13524. (c) Kozmin, S. A.; Iwama, T.; Huang, Y.; Rawal, V. H. J. Am. Chem. Soc. 2002, 124, 4628-4641. (d) Johnson, P. D.; Sohn, J. H.; Rawal, V. H. J. Org. Chem. 2006, 71, 7899-7902. (e) Hayashida, J.; Rawal, V. H. Angew. Chem., Int. Ed. 2008, 47, 43734376.

(11) For selected examples, see: (a) Gagnon, A.; Danishefsky, S. J. Angew. Chem., Int. Ed. 2002, 41, 1581-1584. (b) Smith, A. B., III; Basu, K.; Bosanac, T. J. Am. Chem. Soc. 2007, 129, 14872-14874. (c) Tang, Y.; Cole, K. P.; Buchanan, G. S.; Li, G.; Hsung, R. P. Org. Lett. 2009, 11, 1591-1594. (d) Spangler, J. E.; Carson, C. A.; Sorensen, E. J. Chem. Sci. 2010, 1, 202-205. (e) Petronijevic, F. R.; Wipf, P. J. Am. Chem. Soc. 2011, 133, 7704-7707.

(12) (a) Freifelder, M. J. Org. Chem. 1964, 29, 2895-2898. (b) Wenkert, E.; Hudlický, T. J. Org. Chem. 1988, 53, 1953-1957. (c) Ludwig, C.; Wistrand, L.-G. Acta Chem. Scand. 1989, 43, 676-679.

(d) Lei, A.; Chen, M.; He, M.; Zhang, X. Eur. J. Org. Chem. 2006, 2006, 4343-4347.

(13) Levine, S. G. J. Am. Chem. Soc. 1958, 80, 6150-6151.
(14) Busch-Petersen, J.; Corey, E. J. Tetrahedron Lett. 2000, 41, 2515-2518.

(15) Minimizations were carried out using Spartan'08 software. See also: Hehre, W. J. A Guide to Molecular Mechanics and Quantum Chemical Calculations; Wavefunction, Inc.: Irvine, CA, 2003.

(16) Reich, H. J.; Renga, J. M.; Reich, I. L. J. Am. Chem. Soc. 1975, 97, 5434-5447.

(17) Ohno, M.; Tanaka, Y.; Miyamoto, M.; Takeda, T.; Hoshi, K.; Yamada, N.; Ohtake, A. Bioorg. Med. Chem. 2006, 14, 2005-2021.

(18) Rulev, A. Y. Russ. Chem. Rev. 2011, 80, 197-218.

(19) Firouzabadi, H.; Iranpoor, N.; Jafarpour, M.; Ghaderi, A. J. Mol. Catal. A: Chem. 2006, 252, 150-155.

(20) For examples of intramolecular aza-Michael reaction, see: (a) Bland, D.; Chambournier, G.; Dragan, V.; Hart, D. J. Tetrahedron 1999, 55, 8953-8966. (b) Cai, Q.; Zheng, C.; You, S.-L. Angew. Chem., Int. Ed. 2010, 49, 8666-8669. (c) Guerola, M.; Sánchez-Roselló, M.; Mulet, C.; del Pozo, C.; Fustero, S. Org. Lett. 2015, 17, 960-963.

(21) Shioiri, T.; Ninomiya, K.; Yamada, S. J. Am. Chem. Soc. 1972, 94, 6203-6205.

(22) Kyo Park, T. K.; Danishefsky, S. J. Tetrahedron Lett. 1994, 35, $2667-2670$

(23) Meerwein, H.; Hinz, G.; Hofmann, P.; Kroning, E.; Pfeil, E. J. Prakt. Chem. 1937, 147, 257-285.

(24) Dess, D. B.; Martin, J. C. J. Org. Chem. 1983, 48, 4155-4156.

(25) The slow interconversion of the two rotamers of $\mathbf{3 4}$ prevented us from obtaining a satisfactory ${ }^{13} \mathrm{C}$ NMR spectrum of this compound, even at high temperatures and with extended experiment times, using either $\mathrm{CDCl}_{3}$ or DMSO- $d_{6}$.

(26) The singlet at $4.88 \mathrm{ppm}$ in the ${ }^{1} \mathrm{H}$ NMR of 36 disappeared when a small amount of $\mathrm{D}_{2} \mathrm{O}$ was added to its $\mathrm{CDCl}_{3}$ solution. 